Winter 2015

\title{
Foreign Attorneys in U.S. LL.M. Programs: Who's In, Who's Out, and Who They Are
}

Mindie Lazarus-Black

Temple University, mindielb@temple.edu

Julie L. Globokar

Kent State University - Kent Campus, jglobok1@kent.edu

Follow this and additional works at: https://www.repository.law.indiana.edu/ijgls

Part of the International Law Commons, Legal Education Commons, and the Legal Profession Commons

\section{Recommended Citation}

Lazarus-Black, Mindie and Globokar, Julie L. (2015) "Foreign Attorneys in U.S. LL.M. Programs: Who's In, Who's Out, and Who They Are," Indiana Journal of Global Legal Studies: Vol. 22 : Iss. 1 , Article 2.

Available at: https://www.repository.law.indiana.edu/ijgls/vol22/iss1/2

This Article is brought to you for free and open access by the Law School Journals at Digital Repository @ Maurer Law. It has been accepted for inclusion in Indiana Journal of Global Legal Studies by an authorized editor of Digital Repository@Maurer Law. For more information, please contactrvaughan@indiana.edu.

\section{$\Psi$}

JEROME HALL LAW LIBRARY

INDIANA UNIVERSITY

Maurer School of Law
Bloomington 


\title{
Foreign Attorneys in U.S. LL.M. Programs: Who's In, Who's Out, and Who They Are
}

\author{
MINDIE LAZARUS-BLACK ${ }^{*}$ JULIE GLOBOKAR*
}

\begin{abstract}
In recent decades, there has been a remarkable growth in the number of foreign attorneys enrolled at U.S. law schools and particularly in LL.M. programs. To learn more about these students and how they fare, we conducted research in two law schools, one in the Midwest and the second on the East Coast. We examine the admissions process for foreign attorneys from the perspectives and experiences of both the administrators who make admissions decisions and the students who seek admission. We consider the layered international, national, state, and local laws that complicate the selection process, as well as the standards set by the schools themselves. To understand who gets in and who does not, we interviewed nine administrators who admit and support the international students during their studies. We observed how accounting practices and techniques of audit culture color administrative decision-making, but also the conditions under which discretion comes into play. We collected quantitative data about the students at the two schools and analyzed their personal statements using the anthropological and linguistic concept of "genre," a stylized narrative, that revealed students' life histories, education, work experiences, motives for attending the programs, and future goals. The narratives, and our interviews with fifty students who attended the programs, demonstrate that internationalization has changed the terms for inclusion in U.S. law schools. The structures of privilege play by different rules at the international level. They include a wider politics of interstate relations, the vicissitudes of international and national law, the operation of audit cultures, a certain proficiency in English as the lingua franca of international law, and the ability to muster economic and other symbolic resources, even under great hardship. As sites of globalization, law
\end{abstract}

* Professor of Anthropology, Temple University.

** Assistant Professor of Sociology, Kent State University.

Indiana Journal of Global Legal Studies Vol. $22 \# 1$ (Winter 2015)

(c) Indiana University Maurer School of Law 
schools are creating new legal experts who will reinvent the future meaning of being a lawyer and doing a lawyer's work.

\section{INTRODUCTION}

In Failing Law Schools, Tamanaha describes an unsettling portrait of contemporary legal education in which the U.S. News and World Report rankings, "in combination with the ABA [American Bar Association] accreditation formula ... had a homogenizing influence on the student body, on the faculty, and across law schools, dampening innovation and diversity. . . . We became what the ranking counted." 1 Without doubt, the demographics of the men and women who will occupy the seats in tomorrow's law school classes are changing. As Tamanaha warns, several factors are leading to a decline in the overall number of law students and of working class, middle class, and minority students in particular. These include the replacement of need-based scholarships by merit-based scholarships based largely on LSAT scores, the cost of tuition for law school, ${ }^{2}$ the disappearance of jobs for lawyers, falling pay scales, and recognition of the enormous debt students acquire if they attend law school.

There is another change in the composition of the class that Tamanaha mentions only in passing and mostly as a possible remedy for filling empty seats: the remarkable growth of foreign attorneys enrolled at U.S. law schools and particularly in LL.M. programs. ${ }^{3}$ The programs have developed quickly in the past several decades-an

1. BRian Z. Tamanaha, Failing LaW Schools 85 (John M. Conley \& Lynn Mather eds., 2012).

2. Between 1985 and 2011 the American Bar Association has documented increases in average law school tuition and fees ranging from eight-fold (with mean private school expenses rising from $\$ 7,526$ in 1985 to $\$ 39,184$ in 2011) to more than ten-fold (with mean in-state public tuition rising from $\$ 2,006$ in 1985 to $\$ 22,116$ in 2011). For in-state public tuition, much of this increase has taken place in recent years, with average tuition increasing from $\$ 10,819$ to $\$ 22,116$ between 2003 and 2011. See Law School Tuition 19852012, AM. BAR ASSOC., http://www.americanbar.org/content/dam/aba/administrative/ legal_education_and_admissions_to_the_bar/statistics/s_tuition.authcheckdam.pdf (last visited Sept. 15, 2014).

3. Following Silver: “'F]oreign' is used to mean an individual licensed outside of the host jurisdiction," and "[a] 'foreign law graduate' with regard to a U.S. law school program is an individual who earned his or her first degree in law from a law school outside of the United States." Carole Silver, The Variable Value of U.S. Legal Education in the Global Legal Services Market, 24 GEo. J. LEGAL ETHICS 1, 5 n.16 (2011) [hereinafter Silver, Variable Value]. 
increase of over 50 percent between 1998 and $2003,{ }^{4}$ totaling 179 LL.M. programs by 2007.5 These programs are the consequence of a myriad of changes in the politics and economics of national and international relations, among them the growth of transnational investments; the relaxation of national borders to international markets and entrepreneurs; new treaties and trade agreements; law firm mergers; and the movement of U.S. firms abroad and foreign lawyers to U.S. law firms. ${ }^{6}$ Yet as Silver notes, "reliable data on this population remain

4. Carole Silver, Internationalizing U.S. Legal Education: A Report on the Education of Transnational Lawyers, 14 CARDOZO J. INT'L \& COMP. L. 143, 147 (2006) [hereinafter Silver, $A$ Report $]$.

5. Julie M. Spanbauer, Lost in Translation in the Law School Classroom: Assessing Required Coursework in LL.M. Programs for International Students, 35 INT'L J. LEGAL INFO. 396, 409 (2007).

6. It is now well established that U.S. firms are expanding into foreign markets, international companies are moving people and offices to the United States, and even lawyers working in solo practice or for the government are navigating new waters and forging and circulating new legal forms and practices. One study published by the American Bar Foundation and NALP Foundation for Law Career Research and Education reported on the careers of more than 4,000 lawyers after approximately seven years in practice:

A large minority of attorneys were doing at least some work that involved clients from outside the United States or cross-border matters. Forty-four percent (44\%) of attorneys reported such work. The lawyers most likely to report doing international legal work were those in the largest law firms, where two thirds reported doing it, and inside counsel, where almost as many $(65 \%)$ reported work that involved nonU.S. clients or cross-border matters. Among legal services and public defense lawyers, work that involved non-U.S. clients or non-U.S. law was also common, with $61 \%$ of attorneys reporting they had done some such work during the past year. The international work in large corporate firms mainly serves foreign corporate clients, while the work of legal services and public defense lawyers likely involves individual clients who are facing immigration issues.

RONIT DINOVITZER ET AL., AFTER THE JD II: SECOND RESUlTS FROM A NATIONAL STUDY OF LEGAL CAREERS 35 (2009). Similarly, a study of the Philadelphia bar conducted in 2009 concludes, "[I]nternational and comparative law are becoming a routine component of legal practice." Susan L. DeJarnatt \& Mark C. Rahdert, Preparing for Globalized Law Practice: The Need to Include International and Comparative Law in the Legal Writing Curriculum, 17 J. LEGAL WRITING INST. 3, 7 (2011). This study discovered that in the five years preceding the survey, attorneys had worked on matters that required them to know about law in more than one nation, and sometimes international law across eighteen different legal specializations. See id. at 54-63 (showing the data collected by the authors). A substantial majority (67.5\%) of those responding to the survey had had experience with such cases. Id. at 20. See also Carole Silver, Getting Real About Globalization and Legal Education: Potential and Perspectives for the U.S., 24 STAN. L. \& POL'Y REV. 457 (2013) [hereinafter Silver, Getting Real], in which she reviews these studies, id. at 467-68, and also makes the important point that the U.S. population is itself increasingly international, id. at 468. See generally the following works that further explore transnational legal practice: Alfred C. Aman, Jr., Globalization: Legal Aspects, in 
scarce." 7 Indeed, with the exception of a few studies, ${ }^{8}$ the experiences of these foreign LL.M. students ${ }^{9}$ in U.S. law schools, the faculty who teach

INTERNATIONAL ENCYCLOPEDIA OF THE SOCIAL \& BEHAVIORAL SCIENCES (James D. Wright ed., 2nd ed. forthcoming 2015) (on file with author) (arguing law has an important role to play in globalization); Global Prescriptions: THe Production, Exportation, and IMPORTATION OF A NEW LEGAL ORTHODOXY (Yves Dezalay \& Bryant G. Garth eds., 2005) (arguing that it is necessary to go beyond legal institutions and reforms to understand law and how it is changing); Yves DeZALAY \& BRYANT G. GARTH, THE INTERNATIONALIZATION OF PALACE WARS: LAWYERS, ECONOMISTS, AND THE CONTEST to TRANSFORM LATIN AMERICAN STATES (2002) (hypothesizing that the results of certain exports of state expertise will depend on the extent of structural homologies in state fields of importers and exporters); CAUSE LAWYERING AND THE STATE IN A Global ERA (Austin Sarat \& Stuart Scheingold eds., 2001) (illustrating the involvement of cause lawyers in the process of globalization and explaining the effects of globalization on cause lawyering); Boaventura de SOUSA SANTOS, TOWARd a NEW LEgal Common SENSE: LAW, GLOBALIZATION, AND EMANCIPATION (2nd ed. 2002) (conducting sociological analysis of law and illustrating the need for reconstruction of the idea of legality based on local, national, and global axioms); Richard L. Abel, Transnational Law Practice, 44 CASE W. RES. L. REV. 737 (1994) (arguing that lawyers, professional organizations, and governments should regulate transnational law practice); Sida Liu, Globalization as Boundary-Blurring: International and Local Law Firms in China's Corporate Law Market, 42 LAW \& Soc'Y REV. 771 (2008) (exploring the global-local relationship as part of the globalization of the legal market, primarily using the case of China); Silver, A Report, supra note 4; Carole Silver, The Case of the Foreign Lawyer: Internationalizing the U.S. Legal Profession, 25 FORDHAM INT'L L.J. 1039 (2002) [hereinafter Silver, The Foreign Lawyer] (suggesting U.S. law firms should consider the extent to which foreign professionals have succeeded in nonlaw professional service firms); Carole Silver, Globalization and the U.S. Market in Legal Services-Shifting Identities, 31 LAW \& POL'Y INT'L BUS. 1093 (2000) (examining how the international work of U.S. law firms can impact the domestic legal services market).

7. Carole Silver, States Side Story: Career Paths of International LL.M. Students, or "I Like to Be in America", 80 FoRDHAM L. REV. 2383, 2389 (2012).

8. Silver's work is unusual in exploring the proliferation of programs designed to provide foreign lawyers with training in U.S. law, the spread of U.S. firms to foreign sites, and employment patterns of foreign lawyers as gleaned from law firm directories. Her research on transnational legal education includes web-based program descriptions, surveys of program directors, analyses of law firm data, and interviews with students, LL.M. graduates in New York law firms, and hiring partners at U.S.-based elite international firms. See generally, CAROLE Silver, LAW SCHOOL AdMission Council, GRANT REPORT 09-01, AGENTS OF GLOBALIZATION IN LAW: PHASE 1 (2009) [hereinafter Silver, AGENTS of Globalization]; Silver, A Report, supra note 4; Carole Silver, Coping with the Consequences of 'Too Many Lawyers': Securing the Place of International Graduate Law Students, 19 INTL'L J. LEGaL Prof. 227 (2012) [hereinafter Silver, Coping with the Consequences]; Silver, The Foreign Lawyer, supra note 6; Silver, Getting Real, supra note 6; Silver, Variable Value, supra note 3 . Our project builds on this body of work, but addresses the more recent period since the recession took its toll on law schools and the profession more generally. Our project also adds an ethnographic component, includes interviews with faculty, and draws on theoretical discussions in anthropology and other disciplines $i w$ raise questions about the implementation of auditing practices, changing forms of zuvernmentality, and the influence of globalization on U.S. law schools. See generally THE EXPORT OF LEGAL EDUCATION: ITS PROMISE AND IMPACT IN TRANSITION 
them, and the administrators who admit and support them through their studies, remain largely unexplored.

In this paper, we examine the admissions process for foreign attorneys, both from the perspectives and experiences of the administrators who make admissions decisions and the students who seek admission. Who gets accepted into LL.M. programs? Who does not? Which types of international, national, and local policies and laws must foreign attorneys navigate if they want to study in the United States? What kinds of political, economic, linguistic, and social capital must they demonstrate to gain admission to law school?

To explore these questions, we draw on interviews, participant observation, and an analysis of admissions documents from two law schools: one in the Midwest and the second on the East Coast. ${ }^{10} \mathrm{We}$ are interested in the layered international, national, state, local, and institutional processes of "selection" as they are complicated by international and U.S. law, as well as the standards set by law school admissions offices. We analyze the personal statements of applicants using the anthropological and linguistic concept of "genre," a stylized narrative, to explore who these students are in greater depth. ${ }^{11}$ Each

CoUNTRIES (Ronald A. Brand \& D. Wes Rist eds., 2009); Lauren K. Robel, Opening our Classrooms Effectively to Foreign Graduate Students, 24 PENN ST. INT'L. L. REv. 797 (2006); Spanbauer, supra note 5.

9. We define "student" as a person who is currently enrolled part-time or full-time in an LL.M. program for foreign attorneys trained outside the United States or who has just completed that program.

10. This article relies primarily on the analysis of student applications to LL.M. programs at these two law schools, as well as interviews with administrators, faculty, and students. As a condition of gaining access to the student files at the two schools, we recorded only demographic information such as country of origin, age, and gender, as well as type of visa and sources of financing (when these were available). As long as we expunged any information that could potentially identify any applicant, we were also permitted to collect as fieldnotes verbatim excerpts from the students' personal statements on the topics of students' life histories, educational and work experiences, academic interests, reasons for wanting to further their education, and future plans. We reviewed student files from the school in the Midwest from 2003 to 2008, and files from the school on the East Coast from 2008 to 2009. Similarly, for the interviews with administrators, faculty, and students conducted at the two schools from 2008 to 2012 , our interview consent form promised anonymity and confidentiality to all subjects. To respect this agreement, the interviews have been grouped in three categories: Administrator (interviews \#1-9); Faculty (interviews \#1-32); and Student (interviews \#1-50). Throughout this paper, we identify our interviewees only by their interview number and status as an administrator, faculty member, or student at one of the two schools. Additional details, such as interview dates, must be excluded to ensure that interviewees within each of the schools cannot be identified.

11. As Bauman explains, a "genre appears as a set of conventional guidelines for dealing with recurrent communicative exigencies," and is a formula for communication that is characterized by "a set of expectations concerning the ... unfolding of the 
personal statement includes voluntary biographical information such as the foreign attorneys' education, work experiences, motives for attending an LL.M. program, and future goals. These narratives are carefully crafted, the purpose of which is to gain their authors a place in a desired academic program. Thus, the narratives are also a study of what foreign attorneys think "we" want to hear. ${ }^{12}$

The analysis of this project contributes to research about how accounting practices and processes of commensuration, ${ }^{13}$ shifting forms

discourse." Richard Bauman, Genre, 9 J. LINGUISTIC ANTHROPOLOGY 84, 84-85 (2000). Jill Ramsfield discusses U.S. legal genres, noting: "In the U.S. law classroom, we primarily use two genres, the judicial opinion and the exam. In clinical courses, seminars, and legal writing courses, we introduce such other genres as motions, interrogatories, pleadings, intraoffice memos, appellate briefs, and client letters." Jill J. Ramsfield, Is "Logic" Culturally Based? A Contrastive, International Approach to the U.S. Law Classroom, $47 \mathrm{~J}$. LEGAL EDUC. 157, 181 (1997). She also makes the important point that "[g]enres vary among legal cultures, even if their names are the same. A brief in a Swedish court of appeals is about ten pages long; a brief in a Michigan court of appeals may be fifty pages long." Id. As we demonstrate, the personal statement is not a genre with which most international LL.M. students are familiar.

12. Law schools provide on their websites basic information about their programs and admissions requirements, but few of the websites offered advice about how to fill out the application or obtain other necessary documents. Cuciurean-Zapan researched online information and advice specifically designed to assist students who want to study in LL.M. programs in the United States. In a nutshell, specific information is hard to find. At the time, search engines like Google turned up three types of information: directories of LL.M. programs, sites offering LL.M. programs, and blog entries pertaining to specific LL.M. programs. Searches on academic databases such as Google Scholar, AnthroSource, and HeinOnline were also unsuccessful. Memorandum from Marta Cuciurean-Zapan, former Research Assistant, to Professor Mindie Lazarus-Black (Feb. 25, 2010) (on file with author). We did not compare the personal statements we collected for this project to those written by JD students or by international students more generally. As we explain, our purpose in reading the LL.M. narratives by foreign attorneys is to offer insights in addition to those that can be gleaned from our own and others' data about the complexity of the backgrounds from which these students come; their motives for study; future goals; and ideas about U.S. law, U.S. lawyers, and U.S. legal education.

13. When we say things are "commensurable," we assume they have "a common measure" or are "proportionate." See RANDOM HOUSE, THE RANDOM HOUSE DicTiONARY OF THE ENGLISH LANGUAGE 411 (2d ed. 1987), for the definition of "commensurable." We discuss later some of the implications (and frustrations) of trying to make people "commensurate." For other discussions of how auditing practices operate in the context of legal education, see generally ElizABETH MERTZ, THE LANGUAGE OF LAW SCHOOL: LEARNING TO "THINK LIKE A LAWYER" (2007) (discussing the relationship between language and thought and the subtle effects of legal education); DEBRA J. SCHLEEF, MANAGING Elites: Professional SOCIALIZATION IN LAW AND Business Schools (2006) (discussing "how elites-in-training contest, rationalize, and ultimately enthusiastically embrace their dominant position in society"); John M. Conley, Can You Talk Like a Lawyer and Still Think Like a Human Being? Mertz's the Language of Law School, 34 LAW \& SOC. INQUIRY 983 (2009) (reviewing ELIZABETH MERTZ, THE LANGUAGE OF LAW SCHOOL: LEARNING TO "THINK LIKE A LAWYER"); Wendy Nelson Espeland \& Mitchell L. 
of "governmentality,"14 and the creation of new international networks ${ }^{15}$ are changing the composition of future law students. Admissions and other administrators are caught up in the "audit cultures" of our times. ${ }^{16}$ They choose students according to the numbers revealed in test scores and transcripts; however, interviews and the method of participant observation yield valuable insights about the circumstances under which administrators leave these hegemonic numbers behind. Our study also illuminates the foreign attorneys' countervailing selfselection; they are "self-managing individuals who render themselves auditable." 17 We learned, for example, that the selection of these students began well before they reached our shores-in China, Brazil, Italy, or Ukraine. For most, self-selection began with examinations in high school, and entrance into legal education in their country of origin

Stevens, A Sociology of Quantification, 49 EUR. J. SoC. 401 (2008) (discussing quantification as a general sociological phenomenon and five sociological dimensions of quantification); Wendy Nelson Espeland \& Berit Irene Vannebo, Accountability, Quantification, and Law, 3 ANN. REV. LAW \& Soc. SCI. 21 (2007) (discussing how the recent emphasis on quantitative accountability has influenced law and legal practices).

14. In a brief and comprehensible definition, Colin Gordon explains: "Governmentality is about how to govern." Colin Gordon, Governmental Rationality: An Introduction, in THE FOUCAULT EFFECT: STUDIES IN GOVERNMENTALITY WITH Two LECTURES BY AND AN INTERVIEW WITH MICHEL FOUCAULT 1, 7 (Graham Burchell et al. eds., 1991). Alternatively, reflecting on "what it meant to govern," Miller and Rose conclude it means "to conduct conduct." Peter Miller \& Nikolas Rose, Governing the PREsent: Administering ECONOMIC, Social, AND PERSONAL Life 14 (2008). See also JACQUeS DOnZelot, The Policing of Families 48-95 (Robert Hurley trans., Pantheon Books 1979) (discussing the relationship between the government and the family as well as how the family authority functions in terms of governing the family members); MiCHEL Foucault, Discipline and Punish: The BirTh of the Prison 170-194 (Alan Sheridan trans., Random House, 2d Vintage Books ed. 1995) (discussing the means of correct training).

15. See generally ANnelise RILES, The NeTwork Inside Out (2000) (examining the networking relationship between Fijian activists and NGOs); SASKIA SASSEN, THE GLOBAL CITY (2d ed. 2001) (discussing the international economic processes that made New York, London, and Tokyo global economic centers); ANNALEE SAXENIAN, THE NEW ARGONAUTS: REGIONAL ADVANTAGE IN A GLOBAL ECONOMY (2006) (discussing U.S.educated foreign nationals who return to their home countries and improve the local technology industries); Michel-Rolph Trouillot, The Anthropology of the State in the Age of Globalization: Close Encounters of the Deceptive Kind, 42 CURRENT ANTHROPOLOGY 125 (2001) (discussing the role of state power in the face of increased globalization).

16. See generally AUDIT CUlturES: ANTHROPOlogiCAL STUdIES IN ACCOUNTABILITY, ETHICS, AND THE ACADEMY (Marilyn Strathern ed., 2000) (a compendium of articles explaining the concept of audit cultures); MiCHAEL POWER, THE AUdi'T SOCIETY: RITUALS OF VERIFICATION (1997) (discussing financial auditing and explaining the concept of auditing in other contexts).

17. Cris Shore \& Susan Wright, Coercive Accountability: The Rise of Audit Culture in Higher Education, in AUDIT CULTURES, supra note 16, at 57. 
is determined by the results of a single examination. ${ }^{18}$ In this way, our subjects are thoroughly "modern"; they have already been observed, tested, normalized, and disciplined. They engage, and are engaged by, contemporary forms of knowledge, power, and discipline. ${ }^{19}$

Given the diversity of their countries of origin, we were fascinated to find within the genre of the international lawyers' personal statements that there exist five distinct, recurring conventions that collectively form what Bunten describes as a "commodified persona," 20 (i.e., a marketable identity) designed to "sell" to a U.S. law school. The personal statements serve a second and equally interesting purpose; namely, they complicate what our own and earlier quantitative data suggest about whom these students "are." The personal statements evince through narrative, and in contrast to what can be discerned from quantitative or survey research, the diverse backgrounds of the LL.M. students; why they want to study in U.S. law schools; and what they think more generally about U.S. law and U.S. lawyers, and the globalization of legal practice and the profession. Our interviews with the students about their decision to attend law school, their experiences with the law school application process, and their mustering of the resources to attend these programs confirmed what we learned from the narratives about the remarkable backgrounds of these students.

18. Erie's account of the admissions process at Tsinghua University Law School in China resonates with those described to Lazarus-Black in her interviews with Chinese students about getting into law school: exam results are critical. See Matthew S. Erie, Legal Education Reform in China Through U.S.-Inspired Transplants, 59 J. LEGAL EDUC. 60, 73-75 (2009) (discussing the bias in China for the LL.M. degree over the Juris Master (JM), and how examination results are crucial for admission to the best LL.M. programs). From another source we learn: "In Serbia, law school applicants are evaluated according to the scores achieved on their admissions test and their high school grades." Milena Dordevic, The Export of American Legal Education and Its Impact in Serbia, in THE EXPORT OF LEGAL EDUCATION: ITS PROMISE AND IMPACT IN TRANSITION COUNTRIES, supra note 8 , at 63 .

19. See FouCAULT, supra note 14, at 135-94 (broadly discussing discipline); MrCHEL FOUCAULT, POWER/KNOWLEDGE: SELECTED INTERVIEWS AND OTHER WRITINGS, 1972-1977 (Colin Gordon ed., 1980), reprinted in ThE FouCAULT READER 51, 51-75 (Paul Rabinow ed., Pantheon Books 1984) (broadly discussing power).

20. Alexis Celeste Bunten, Sharing Culture or Selling Out?: Developing the Commodified Persona in the Heritage Industry, 35 AM. ETHNOLOGIST 380, 381 (2008) (explaining how some members of the Tlingit people in Alaska have learned to sell themselves and their culture to tourists from the United States). It is possible that attorneys might also write personal statements to educate U.S. admissions officers about legal education and the profession in their home country. We do not discount that notion, but anecdotal data in Lazarus-Black's interviews with LL.M. students suggests that the students' primary concern was selling themselves as admissible candidates for the programs. 
Our analysis is pertinent to several audiences, including scholars interested in the phenomena of border crossings and internationalization, faculty who teach foreign law attorneys, administrators concerned with these students' admission and welfare, and legal professionals attuned to the ways in which the profession of law is globalizing. Moreover, our account provides an empirical example of how the process of globalization "is deeply embedded within domestic institutions,"21 which in this case is the institution of the law school.

Our discussion unfolds as follows. In Part I, we describe our two field sites, research methods, and a brief quantitative profile of the students. We worked in what one of our interviewees, a faculty member in the Midwest, called a "regular" law school, and that characterization holds as well for the second school. ${ }^{22}$ Consequently, the students whose admissions files we read and who we interviewed are "diverse"; typically, they are not the sons and daughters of the most elite strata in their countries of origin.

In Part II, we sample as ethnographic documents some of the key federal, state, and local statutes that govern who can come to the United States to study as LL.M. students. We also examine interviews with admissions officers and other administrators at the two schools to reveal the structural, political, economic, and occasionally idiosyncratic issues that influence their decisions to admit or deny applicants. We demonstrate the ways in which required documents and the questions administrators ask about those documents are informed by the hegemonic characteristics of audit cultures and processes of commensuration. Admissions counselors, for example, do not know what to make of an applicant who is declared an "upstanding citizen" because there is no way for them to determine how such a student compares to peers. This discussion closes with our finding about the ability of law students to select themselves into the programs to which they apply.

In Part III, we present our analysis of more than 300 personal statements from the school in the Midwest. We illustrate our analysis with excerpts from the narratives demonstrating the conventions that

21. Aman, supra note 6, at 6; See Mindie Lazarus-Black, The Voice of the Stranger: Foreign Law Students' Experiences of Culture, Law, and Pedagogy in American Law Schools (May 25, 2013) (unpublished manuscript) (on file with author).

22. The faculty member attended an Ivy League school on the East Coast and interacted with international law students there, many of whom were the offspring of the elite in their countries of origin and would return home to prestigious jobs. The context of the discussion made it clear to Lazarus-Black that his characterization of the school in which he was now teaching as "regular" was in contrast to the elite school in which he had trained. He explained that his current students were likely to be "ordinary lawyers" who were "serving clients." Interview with Faculty \#29, School in Midwest. This and all subsequently referenced interviews are on file with Lazarus-Black. 
comprise an international law student's application for admission to an LL.M. program. We find structural similarities in these narratives despite the students' different backgrounds, but also remarkable diversity and complexity in their life histories. We later suggest that the composition of classes of international LL.M. students is changing over time.

In Part IV, we use the narrative of one student, "Asmar," to illustrate how the conventions coalesce in a single application. "Asmar's" narrative also supports Ballakrishnen's surprising finding that lawyers in India decide to study in the United States for personal and intellectual reasons despite that the U.S. LL.M. degree is only sometimes useful in terms of future employability in India. ${ }^{23} \mathrm{We}$ also review a second set of narratives, drawn from the school on the East Coast, to test the validity of the conventions of the genre.

Finally, we present in Part $\mathrm{V}$ what students told us in interviews about their motivations, preparations, and experiences in applying to law schools. These findings enriched our analyses of the quantitative data and the narratives, further enabling us to understand with greater insight the foreign attorneys attending the schools in which we worked. In our final discussion, we conclude by raising two issues that warrant further attention based on our findings; namely, the changing terms of "inclusion" in legal education and the profession, and the case of the law school as a site for understanding the complex processes of globalization.

\section{Field Sites, Research METHODS, AND A QUANTITATIVE PROFILE OF THE PARTICIPANTS}

We worked in two law schools, one in the Midwest and the other on the East Coast, both of which offer a traditional JD program and several specialized LL.M. programs. We focused on the LL.M. programs that admitted international students. Both schools are accredited by the American Bar Association and are members of the Association of American Law Schools. Although LL.M. programs are not ranked by U.S. News and World Report, the two law schools in which the programs are housed fall within the top seventy-five schools in the hierarchy. ${ }^{24}$

At both schools, students are required to complete twenty-four credit hours of study, of which two courses are specifically designed for

23. See Swethaa Ballakrishnen, Homeward Bound: What Does a Global Legal Education Offer Indian Returnees?, 80 FORDHAM L. REV. 2441, 2465 (2012).

24. See Best Law Schools, U.S. NEWS \& WORLD REPORT, http:/gradschools.usnews.rankingsandreviews.com/best-graduate-schools/top-law-schools/lawrankings (last visited Oct. 28, 2014). 
foreign students. With the aid of advisors, students select their remaining courses, which they take alongside traditional JD students. Some students in our sample attended special programs that allow graduates of foreign law programs to partially fulfill their degree requirements for the LL.M. degree in their countries of origin or at a satellite campus of the law school. In these cases, the students are taught in short, intensive classes by faculty from the law school and then complete their final semester in the United States. Other students study in the United States for the full year; they enroll in courses, prepare for classes and exams, and follow other routines designed to make them think and act like U.S. lawyers. ${ }^{25}$

The international students at both schools we studied come from many different countries, backgrounds, and educational and legal systems. Selection involves processing foreign and local documents, immigration forms, bank statements, test scores, reference letters, and personal statements. The forms with which we engage tell stories about their makers, ${ }^{26}$ rendering these documents rich data sources for a study of the admissions process and application experience. Our analysis of these documents allows us to pursue "an ethnographic understanding of the character of contemporary institutional knowledge."27

We used a combination of quantitative and qualitative research methods to assess the process by which foreign lawyers are accepted into U.S. LL.M. programs and what their applications and interviews can tell us about them. Globokar collected and analyzed the statistical data about the students from the admissions files at both schools for the years 2003-2008. ${ }^{28}$ We both conducted participant observation in one of the admissions offices and reviewed websites, brochures and handouts, syllabi, and textbooks relevant to the project. Lazarus-Black interviewed nine administrators involved with various aspects of admissions and student success, fifty international LL.M. students, and

25. There is extensive literature on the subject of how one learns to "think like a lawyer." For some recent reviews see Conley, supra note 13, at 983; Erie, supra note 18, at 73-75. See also DUNCAN KENNEDY, LEGAL EDUCATION AND THE REPRODUCTION OF HIERARCHY: A POLEMIC AGAINST THE SYSTEM (2004) (proposing that legal education propagates class and social hierarchies); MERTZ, supra note 13 (specifically dealing with "thinking like a lawyer"); James R. Elkins, The Quest for Meaning: Narrative Accounts of Legal Education, 38 J. LEGAL EDUC. 577 (1988); James R. Elkins, Rites de Passage: Law Students "Telling Their Lives", 35 J. LEGAL EDUC. 27 (1985) (collecting a view of legal education from the student perspective).

26. See generally Don Brenneis, Reforming Promise, in DocUmenTs: ARTIFACTS of MODERN KNOWLEDGE 41 (Annelise Riles ed., 2006) (examining the essays and documents used in grant proposals).

27. RILES, supra note 15 , at 16.

28. For this study, a total of 484 student files were evaluated at the East Coast school and 343 at the Midwest school. 
thirty-two faculty members from the two schools. ${ }^{29}$ We are fortunate to supplement our interviews and compare some of our findings with Silver's survey and interviews that she conducted with admissions officers and foreign attorneys in an earlier period. ${ }^{30}$

What does a quantitative profile of the foreign attorneys reveal? Our access to the administrative files at the two schools allowed us to collect data on age, gender, country of origin, and, to some extent, type of visa and sources of funding.

Although there was a wide age range-from twenty-one to fifty-four years at the Midwest school and twenty-one to sixty-one years at the East Coast school-the students at both schools had an average age of about thirty (Midwest school mean $=29.3$ years; East Coast school mean $=30$ years). ${ }^{31}$ Some of the youngest students included the handful of exchange students that each school admitted through special agreements with select institutions abroad. Most of the students at both schools were female $(58.2 \%$ in the Midwest and $53.3 \%$ on the East Coast). ${ }^{32}$ Interestingly, while the admissions officers in our study were very concerned with international diversity, they did not specifically mention gender as a variable they considered in evaluating a candidate, possibly because women were already overrepresented in their LL.M. student bodies.

The majority of enrolled students hailed from Asia, as represented by the three most common nations of origin at both schools. ${ }^{33}$ China was

29. Lazarus-Black also engaged in participant observation at one school, spending time in classes designed to teach legal research and writing to foreign LL.M. students and at other events sponsored by the law school for these students. She spent time with students before, during, and after classes in addition to conducting the formal interviews.

30. See generally SILVER, AGENTS OF GLOBALIZATION, supra note 8 (featuring several tables with data from foreign sources).

31. National comparative statistics on the ages of JD students could not be located, but at least for the one school studied for which information is available to us, our data indicate that LL.M. students had a higher average age than the overall incoming law student body.

32. By comparison, the JD student body in the U.S. had a slight male majority throughout the time period under study, ranging from $51.3 \%$ to $53.1 \%$. See First Year and Total J.D. Enrollment by Gender 1947-2011, AM. BAR Ass'N, http://www.americanbar.org/ content/dam/aba/administrative/legal_education_and_admissions_to_the_bar/statistics/jd_ enrollment_1yr_total_gender.authcheckdam.pdf (last visited Sept. 14, 2014).

33. The concentration of Asian enrollments in both programs stands in contrast to JD programs, in which Asian students composed only 7.0\% of total enrollments as of the 2011-2012 school year. Calculated from Asian J.D. Enrollment: 2010-2012, AM. BAR Ass'N, http://www.americanbar.org/content/dam/aba/administrative/legal_education_and_ admissions_to_the_bar/statistics/jd_enrollment_asian.authcheckdam.pdf (last visited Sept. 14, 2014) and Enrollment and Degrees Awarded: 1963-2012 Academic Years, AM. BAR ASS'N, http://www.americanbar.org/content/dam/aba/administrative/legal_education 
most heavily represented, though more prominently in the Midwest $(46.9 \%)$ than on the East Coast (20.6\%), ${ }^{34}$ followed by Thailand (10.5\%) in the Midwest and Taiwan (8.1\%) on the East Coast. India was the third most common nation of origin in both programs $(7.9 \%$ in the Midwest and $7.4 \%$ on the East Coast).

It is interesting to compare the demographic characteristics of the students from our two schools to those surveyed by Silver in an earlier period. Her sample of 360 LL.M. graduates from the classes of 1996, 1998, and 2000 represents eleven U.S. LL.M. programs. The median age in Silver's sample was only slightly younger than ours (twenty-eight years), but contained a much lower percentage of females (34\%) and a greater concentration of students born in the European Union (32\%) rather than in Asia-Pacific countries (25\%). ${ }^{35}$ She predicted enrollment might shift to greater numbers of students from Asia, ${ }^{36}$ consistent with the findings in our sample. ${ }^{37}$ An astute law professor mentioned to Lazarus-Black that Chinese women are increasingly enrolling in LL.M. programs to gain skills to offset the informal social connections of their male colleagues, advance the social mobility of their families, and increase their English skills so that they can attract more clients. Marriage and children did not deter these lawyers; their husbands encouraged their studies abroad and their parents stepped in to take care of their children.

Both programs grew substantially in the period under study, beginning with fewer than forty students in 2003 and growing to more than 100 at each school in 2008. While the overall trend was similar, the patterns of growth within this period were different between the two programs. The Midwestern school's LL.M. program grew rather steadily during most years under study, primarily as the result of an expansion in their programs abroad. In the East Coast program, most of the increase occurred during a single school year, after which the program experienced only incremental growth. As we discuss later, the East

_and_admissions_to_the_bar/statistics/enrollment_degrees_awarded.authcheckdam.pdf (last visited Sept. 14, 2014).

34. This was reflective of the greater diversity of the school on the East Coast, which our data indicate had students representative of seventy-eight countries of origin relative to forty-one nations at the program in the Midwest.

35. See Silver, AgENTS OF Globalization, supra note 8, at 5.

36. See id.

37. In analyzing survey data of LL.M. students who earned their degrees in 1996, 1998 , or 2000 , Silver suggested: "The regional distribution of respondents likely is quite different than that of today's group of LL.M. from the same schools. The EU countries are not as well represented today, in large part because of the popularity of EU exchange and graduate programs on the one hand, and the development of high-quality LL.M. programs in other common law, English-speaking jurisdictions ...." Id. 
Coast program administrators made the decision to limit further growth.

In the Midwest, most files contained information about students' anticipated funding sources. ${ }^{38}$ The greatest concentration of students stated that they would personally fund their education (ninety-three, $27.1 \%$ of all students), use family funds (seventy-two, $21 \%$ ) or pay for it through a combination of scholarships and family funds (seventy, $20.4 \%$ ). Some students relied on employer funds (ten, $2.9 \%$ ), others on scholarships alone (five, 1.46\%), or, most commonly, some other combination of two or more funding sources, including scholarships, grants, personal funds, family funds, friends, employers, or "other." 39

Funding information was only available for 25\% of East Coast students, but of those for whom information was available, $43 \%$ reported at least some funding from a sponsor (such as an employer or government body) or scholarship; $25.6 \%$ only listed family sources; $24.8 \%$ provided at least some personal funding. Only five students $\mathbf{( 4 . 1 \%}$ of those for whom information was available) listed loans as an anticipated source; two students listed "friend" as their source of funding.

It has been common in the literature, particularly in studies that include "elite" schools in their analyses, ${ }^{40}$ to presume that foreign law students are drawn from wealthy classes. Alternatively, Healey has suggested, "the recent rapid increase in students studying outside their home countries has come from, disproportionately, the middle-classes of

38. Of the 343 student files that we analyzed for this study, funding sources were identified in 303 files (88.7\%).

39. For example, twenty students indicated scholarship and "other" funding, seventeen indicated scholarship and personal funding, four students indicated family and personal funding, two students indicated scholarships and funding from friends. Silver's survey on international law graduates found: "Approximately $40 \%$ of respondents reported relying exclusively on personal or family savings to finance their US law studies, and fewer than $2 \%$ were supported exclusively by their US law school." Silver, Coping with the Consequences, supra note 8 , at 230. Ballakrishnen's study of nineteen lawyers who completed LL.M. programs in the United States and returned to India also documents the considerable financial burden of attending these programs and the variety of sources of funding that students garnered: "Thirteen respondents had partial tuition waivers, four received full waivers; and the remaining two had some sort of financial support either from the school or a supporting institution." Ballakrishnen, supra note 23, at 2466 n.106.

40. See generally YVES DEZALAY \& BRYANT G. GARTH, DEALING IN VIRTUE: INTERNATIONAL COMMERCIAL ARBITRATION AND THE CONSTRUCTION OF A TRANSNATIONAL Legal ORder (1996); Ugo MatTei \& LAURA NADER, Plunder: WHEN THE RULE OF LAW IS Illegal (2008); Silver, A Report, supra note 4, at 173. This is possibly due in part to the process of obtaining a student visa, which specifically requires that applicants demonstrate their ability to afford tuition and living expenses. 
fast-growing developing countries . ..."41 The data available from the two schools supports the more complex portrait of privilege Healey painted. Clearly, students who are able to support their international studies through personal or family funds or employer support are, to some extent, advantaged. At the same time, many students in the study anticipated payment for their education through a piecing together of multiple sources of support. As will come to light in an analysis of the narratives and interviews with administrators, faculty, and students from these two "respectable," although non-elite, schools, even "personal" and "family" funding can reflect a wide array of statuses of economic privilege; some individuals and families pay outright while other students are left to cobble together borrowed funds from very extended family to meet the legal requirement for a visa, or pay for their own education only after working for years in a less prestigious field to save the necessary funds.

The information on the students in these programs runs counter to the blanket characterization of law schools as bastions of increasing privilege and homogeneity. While this characterization is likely true within some law schools and in regard to some populations, there is also a story to be told about the recent internationalization of legal education. Undoubtedly, the students in this study were privileged with respect to some social and economic variables, but not uniformly so. The population was internationally diverse, disproportionately female, and, in many instances, from nations with developing economies. For some, a U.S. legal education presented a mechanism to surmount gender or class barriers to career advancement in their home countries. As the next section will reveal, an examination of students' paths to the United States further complicates the notion of privilege. Students' paths to the United States are riddled with multilayered hurdles that interact with their nationality, class status, and language fluency to shape their experiences.

\section{GATEKEEPING}

When they decide to study in the United States, foreign attorneys must contend with multiple layers of "selection." Students interested in studying abroad begin that process by obtaining the required papers from their countries of origin. ${ }^{42}$ Students then encounter U.S. federal

41. Nigel M. Healey, Is Higher Education Really 'Internationalising'? 55 HIGHER EDUC. 333, 349 (2008).

42. These requirements vary among countries and depend in part upon the individual's status, connections, and finances. Given that the admissions documents represented 
regulations that, since $9 / 11$, are quite onerous. ${ }^{43}$ Said one admissions officer of the time it takes to navigate through the U.S. process:

You don't just go in and get an appointment the next day. You go in with all your documents and you get an appointment two or three or four weeks out, and sometimes even more than that. And if you are denied, then you have to get a re-hearing, then that takes even more time. Whereas I know with other countries, you can literally go in with your documents and get your visa. $^{44}$

Not surprisingly, students from countries with strong positive political alliances with the United States have the fewest barriers to overcome, whereas students from countries with hostile relations to the United States have very little possibility of obtaining the visa necessary to attend law school here. As revealed in one interview:

Administrator: We're working with one student . . . for probably three or four years now, he wants to come here, he lives in the northern region of Pakistan and apparently there's like an Al Qaeda or Taliban stronghold in that area. About a year or two ago I remember actually seeing his town on the news and the director kept saying, "Well, he's from Pakistan, he's not being admitted." . . He expresses every year his desire to come here and study, but given where he's from-

Lazarus-Black: The U.S. government is denying him year after year?

Administrator: Yes. ${ }^{45}$

Another officer at this school reported:

applicants from dozens of nations of origin, we did not make those requirements a subject of our inquiry.

43. One administrator in the Midwest was the DSO (designated school official) for SEVIS, the Student Exchange Visitor Identification System, the database that tracks visitors and students since 9/11.

44. Interview with Administrator \#6, School in Midwest.

45. Interview with Administrator \#4, School on East Coast. 
They [the federal regulators] basically have a presumption that every person who applied for a student visa really is ultimately permanently trying to be here in the United States, so [the students] have to disprove that by showing that they own properties or that they have a job waiting for them ... [or that] they have a letter from their employer showing that they'll hold a job or the employer has said, "[w]e have asked this person to ... get this additional training to come back and help us grow our business." That can be a problem. . . . It used to happen a lot in China ... and also in Africa and then in the Middle East. . . . The Islamic countries, they have to start really early and it takes a longer time because there's a separate background check that they do for people from a certain group of countries. . . .46

As these examples suggest, visas are central to the gatekeeping process. Students seeking entry to the United States must first gain admittance to a qualifying academic program and obtain an I-20 form from the school to verify their admission. ${ }^{47}$ One member of the office for international affairs described the I-20 as "technically the certificate of eligibility for non-immigrant status." 48 The I-20 allows the student to apply for an F-1 visa, held by most students at both schools, ${ }^{49}$ which enables students to remain in the United States for the duration of their program (one or two semesters) and for up to sixty days afterward to

46. Interview with Administrator \#5, School on East Coast.

47. See Bureau of Consular Affairs - U.S. Dep't of State, Student Visa, U.S. VISAS, http://ravel.state.gov/content/visas/english/study-exchange/student.html (last visited July 29, 2013).

48. Interview with Administrator \#5, supra note 46.

49. In conducting our research, we found that data on visa type was most available in the student files in the school in the Midwest. In our review of this data from our sample (2003-2008), most students (227, 65\%) held F-1 visas; several others (thirty, 8.6\%) still had $\mathrm{J}-1$ visas on file from their participation in exchange programs, but were presumably in the process of securing new visas that would allow them to study full-time in the LL.M. program. (J-1 visas are strictly for exchange programs.) See J-1 Visa Basics, U.S. DEP'T OF STATE, http://j1visa.state.gov/basics/ (last visited Oct. 31, 2014). A few students indicated they were in the U.S. as investors (three students), temporary workers (one student), dependents of temporary workers (seven students), members of foreign militaries (two students), and fiancées (one student). There was no information available for sixty-three of the students. Data on visa type was not regularly included in students' files on the East Coast, but an administrator there estimated that "95 to 97 percent of the international student body [held] F-I visas." See Interview with Administrator \#5, supra note 46. Based on Lazarus-Black's interviews with students, work experience and internships in the U.S. are highly sought after, but anecdotal evidence from students, faculty, and administrators suggests that during the time of our study jobs and internships were hard to find. 
arrange for departure, to transfer to a new school, or to participate in another training program. ${ }^{50}$ Considerable surveillance precedes the issuance of this form and the accompanying visa. A significant requirement is that the student must prove she has sufficient funding to cover tuition, room and board, and expenses for the duration of the time of study. An administrator on the East Coast, for example, told LazarusBlack that students needed to prove that they could pay tuition, had $\$ 10,000$ to cover living expenses for the year, and had $\$ 1,700$ to pay for medical insurance and other incidentals. ${ }^{51}$ At the federal level, once the visa is granted students are bound by ongoing stipulations tied to their status.

Federal and state laws continue to shape these students' experiences well after the admissions decision. During one orientation program at the school on the East Coast, an advisor spent more than an hour outlining the rules students must follow to maintain F-1 status: (1) register for and successfully complete nine semester credit hours each academic term; (2) keep current all the required documents; (3) keep copies of certain documents with them at all times; (4) maintain appropriate health insurance; (5) work no more than twenty hours a week on campus; and (6) not work anyplace else unless authorized to do so. On this final matter, the advisor assured the students that, if caught working without proper authorization, they would be marched away in handcuffs and deported. ${ }^{52}$ Students in the East Coast law school's state

50. U.S. DEP'T OF HOMELAND SEC., Study in the States: Maintaining Your Status, http://studyinthestates.dhs.gov/maintaining-your-status (last visited Sept. 4, 2014) (describing requirements for maintaining and changing immigration status for F-1 visa holders). The F-1 visa is required to enter the country for attendance at a university or other qualifying educational institution or practical training program. See Bureau of Consular Affairs - U.S. Dep't of State, supra note 47.

51. Interview with Administrator \#5, supra note 46. The numbers provided were true for the year of the interview. The specific numbers vary by year and institution. Administrators and faculty are aware that some students cobble together money from personal resources, family, extended kin, and friends to secure the amount they need to satisfy the U.S. requirement that they be self-sufficient during the time they spend in the United States. Id. For example, a faculty member at the school on the East Coast said, "I did a terrible thing once. One student came here and I gave him a B in the course. Told me he came from India. The local people raised all the money to send him here, and if he didn't get an A he can't go back to the group because he's ashamed." Interview with Faculty \#4, School on East Coast. This is in accord with our argument about the diversity of socioeconomic backgrounds of the foreign attorneys we interviewed.

52. An East Coast school advisor explained that employment on campus was the best option for those who wanted to work while taking classes, although international students do not qualify for money under the Federal Work-Study program. See Interview with Administrator \#5, supra note 46. Most LL.M. students who participated in this project stated that they did not hold a steady job because the requirements of the programs are so demanding, although a few students mentioned to Lazarus-Black in informal 
are ineligible for a driver's license because the program ends in ten months and state law requires an intended year of residence. This constrains where the students can live relative to campus. More importantly, each state has different regulations about who is eligible to sit for the bar examination. In both states in which we worked, foreign attorneys are prohibited from applying for the bar based solely on their completion of an LL.M. degree from an accredited U.S. law school. Students at both schools who want to practice in the United States generally sit for the New York bar exam because New York is liberal regarding the credentials that foreign lawyers must hold to take the test. ${ }^{53}$

As applicants negotiate these significant federal, state, and local legal hurdles, they are also confronted with the admissions process of their intended program. In the admissions offices, a number of different agendas compete and frame who gains access to these programs. The admissions process relies very heavily on the dominant themes and characteristics of audit cultures more generally: (1) accountability; (2) objectivity; (3) authenticity; and (4) economic viability. ${ }^{54}$

The admissions standards are similar at the two schools. Each student's application includes information about educational and work experience, transcripts, a language exam score, letters of recommendation, and a personal statement. The vast majority of students in our sample have a foreign law degree, although both schools also had programs in place to host a few exchange students still working on their first law degree in their home country. Our data indicate that the distinctions between the two schools in terms of the formal qualifications for admission involved minor variations in the application

conversations that they occasionally worked for their employers at home by e-mail or telephone, earned a little cash by language tutoring or babysitting, or went home during school breaks to work on their own cases that were still in progress.

53. During the period of our data collection, graduates of foreign law schools were eligible for admission to the bar in New York once they completed twenty semester hours of basic U.S. law courses (the LL.M. degrees at the schools in which we conducted research are twenty-four credits) or another graduate degree from an ABA-approved school. NAT'L CONFERENCE OF BAR EXAM'RS \& AM. BAR ASS'N SECTION OF LEGAL EDUC. AND ADMISSION TO THE BAR, COMPREHENSIVE GUIDE TO BAR ADMISSION REQUIREMENTS 2009 30, 33 (Erica Moeser \& Margaret Fuller Corneille eds., 2009). The Midwestern state in which we worked required a foreign law school graduate to have practiced law for five of the preceding seven years and to have their qualifications deemed acceptable by the board of bar examiners. $I d$. at $30-34$. In the East Coast state, a foreign applicant needed to show evidence of having practiced for five of the past eight years and of having completed thirty credit hours in specified subjects at an ABA-approved law school. Id.

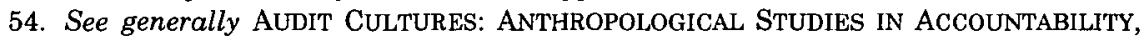
ETHICS, AND THE ACADEMY, supra note 16 (discussing audit culture). 
fee, ${ }^{55}$ the required number of letters of recommendation, ${ }^{56}$ and the minimum Test of English as a Foreign Language (TOEFL) scores. ${ }^{57}$ Both schools also review other evidence of English proficiency, such as the International English Language Testing System (IELTS) score or a certificate from an "English as a Second Language" program. Each school admits some students with lower test scores if their qualifications are otherwise strong. In some cases, admission is conditionally granted upon the student's completion of an intensive English course.

Consistent with the nature of audit cultures, administrators at both schools reported that their evaluations of student applications began with an examination of numbers. The quantitative scores for various tests and grades are critical. One admissions officer at the school in the Midwest explained: "First, I check for completeness, and in terms of the weighing of the various elements . . . the first thing $I$ do . . . is to look at the TOEFL score." She then considers the university or law school transcript. Admitting, "[W]e, of course, are not Harvard here," she still looks for people who hold "the top degree in their jurisdiction." She gave quantitative criteria primacy because "the letters of recommendation are never bad, so, you know . . . you just assume the letter of recommendation is going to be good." She qualified that remark in this way:

In a marginal case, it might be that the letter could tell you something that would help you make a decision to admit; for example, there have been letters which say, you know, "this student's GPA does not reflect their academic ability and here are the reasons why." Remember that all these letters, generally, are written by people for whom English is their second or third language, and coming from systems where there are hundreds of students in a class, and it may not really be the case that the professor has intimate knowledge of the student. So sometimes the letters are a little bit cookie-cutter, and you can see that, especially when the students submit two or three letters, and the letters look

55. While we conducted our fieldwork, one school had an application fee of $\$ 50$; the other was $\$ 75$.

56. At the time of our study, one school required two references and the other required three.

57. At the time that this data was collected, the minimum required score varied depending upun whether the student took the paper, computer, or internet exam, but the difference ietween the two schools' requirements was between ten and thirty points for TOEFL exams. 
almost identical, that the student submitted their letter to the reviewers, and the reviewers just basically put their names to the letter. So, that's a problem and I really can't give those letters too much weight. 58

By contrast, another admissions officer observed: "references are very important to us, to hear how that student would compare to people with similar levels of experience and abilities,"59 although she also acknowledged the often superficial quality of the reference letters. Notice how her words exemplify her participation in audit culture, a culture in which being "an upstanding citizen," "moral," and "upright" does not tell you anything:

[T]here are some countries where students submit references that are just boilerplate, they're very, written so generically: "John Smith was a student in my class. $\mathrm{He}$. . . was a fine young man, an upstanding citizen." I don't know what that means! I wanna know how does John Smith compare to Joe Jones, that's sitting next to him, was he the one that did the best in the course? Did he have the most outstanding paper? Did he, was he heads and shoulders above the others in terms of his extracurricular ability? Those are the things I want to know, and for someone to tell me that this person is moral and upright, which is sometimes a term you'll see, you know? Or he was a student in the class or punctual, that doesn't tell me anything. 60

The administrator's frustration, of course, stems from her need to measure one applicant against another. As Espeland and Stevens explain: "Commensuration creates a specific type of relationship among objects. It transforms all difference into quantity. In doing so it unites objects by encompassing them under a shared cognitive system."61 Hence what is an administrator to do with a student who is "moral" or "punctual"? How are those characteristics to be weighed by a U.S. law school?

The admissions officers also consider the applicant's personal statement. As we show in the next section, these are fascinating anthropological documents in their own right. In line with our

58. Interview with Administrator \#6, supra note 44.

59. Interview with Administrator \#2, School on East Coast.

60. Id.

61. Espeland \& Stevens, supra note 13 , at 408 . 
discussion of the role of audit culture in the admissions process, however, we bring attention first to the use of the personal statement in a manner we had not anticipated. While admissions officers attend closely to the constructed identity of the applicants (where they went to school, their experiences beyond the classroom and at work, and why they want to attend this particular institution), they also use the narrative as a test to measure against the English language examination score. As one administrator explained:

The level of grammar and the competence of the essay should match in some way the statistical data on what their English capability is. So someone who has a marginal TOEFL who writes a perfect essay, then I know the essay was edited at least by someone else, if not written by someone else. I worry about that. ${ }^{62}$

The personal essay, then, is potentially indicative of plagiarism, a phenomenon that worries administrators and faculty a lot, and about which much has been written in the literature on legal education. ${ }^{63}$

62. See Interview with Administrator \#6, supra note 44. This was confirmed by an interview with Administrator \#3, School on East Coast.

63. Cuciurean-Zapan's review of recent literature on plagiarism in the field of legal education found that plagiarism is consistently raised as a topic of concern in law school, but empirical research on plagiarism is limited and the subject is often treated as a matter of ethical and legal concern. Memorandum from Marta Cuciurean-Zapan, former Research Assistant, to Professor Mindie Lazarus-Black (May 22, 2010) (on file with author). Scholars have struggled to define plagiarism in a consistent fashion, to educate students about what plagiarism is, and to implement congruous policies and sanctions when it occurs. See, e.g., Robert D. Bills, Plagiarism in Law School: Close Resemblance of the Worst Kind?, 31 SanTa Clara L. Rev. 103 (1990); Terri LeClercq, Failure to Teach: Due Process and Law School Plagiarism, 49 J. LEGal EdUC. 236 (1999); Michael Sean Quinn, "Scholarly Ethics": A Response, 46 J. LEGAL EDuc. 110 (1996); David J. Shakow, Computers and Plagiarism, 42 J. LEGAL EDUC. 458 (1992). Others are concerned with plagiarism as a phenomenon that occurs among law professors and sometimes between law professors and their students. See, e.g., Ronald K. L. Collins, A Letter on Scholarly Ethics, 45 J. LEGaL Educ. 139 (1995); Lisa G. Lerman, First Do No Harm: Law Professor Misconduct Toward Law Students, 56 J. LEGAL EDUC. 86 (2006); Desmond Manderson, Asking Better Questions: Approaching the Process of Thesis Supervision, 46 J. LEGAL EDUC. 407 (1996); Deborah L. Rhode, The Professional Ethics of Professors, 56 J. LEGAL EDUC. 70 (2006). Pennycook notes: "An understanding of the notion of authorship and originality as a very particular cultural and historical orientation to meaning raises profound questions about plagiarism." Alastair Pennycook, Borrowing Others' Words: Text, Ownership, Memory, and Plagiarism, 30 TESOL Q. 201, 211 (1996). Gader-Shafran's guide to law schools in the United States raises the issue of plagiarism five times. See RACHEL Gader-Shafran, THE INTERNATIONAL STUdENTS' SURVIVAL GUIDE TO LAW SCHOOLS IN THE UNITED STATES: EVERYTHING YOU NEED TO SUCCEED 11-12, 41-42, 49 $50,57-60$ (2003). Both Nilon and Spanbauer draw attention to different styles in the 
Concern for "authenticity" and "objectivity" also shape the admissions personnel's evaluations of the documents and the packages in which documents arrive. Is there a watermark on the transcript? Did the transcript arrive in a sealed envelope with an appropriate return address? Did the letter come directly from the employer? The administrators agreed that if they suspected that a document lacked "authenticity" on the basis of the packaging in which it arrived, the student was unlikely to be admitted. Sometimes, form trumps substance. At one school, students who complain of the difficulty of securing papers deemed authentic by U.S. standards are referred to a professional company, which, for a fee, will authenticate the papers to the satisfaction of the law school.

Another regular consideration of admissions officers was applicants' demonstrated "survivorship." Has the student already traveled, studied, or worked abroad? Is the student going to be able to succeed in a big city? In one administrator's words:

We need to have students who are going to be able to survive, they are going to be able to get housing, they are going to be able to go back and forth between housing and school, they're going to be able to be disciplined about their social lives because of the tantalizing opportunities that exist in the big cities that waste time [and] can really have a very deleterious

attribution of sources in the common and civil law traditions. Nilon creates "a calculus of plagiarism . . . a method by which plagiarism may be systemically analyzed and addressed." Robin Nilon, The Calculus of Plagiarism: Toward a Contrastive Approach to Teaching Chinese Lawyers, 2 S.C. J. INT'L L. \& BUS. 1, 9 (2006); Spanbauer, supra note 5, at 410 (discussing foreign students' unfamiliarity with the Anglo-American common law and the importance of adequate English language skills). Particularly interesting is the finding that students who are not initially trained in a U.S. legal setting experience a kind of culture shock when they are exposed to the U.S. system of appropriate citation. See, e.g., Nilon, supra; Pennycook, supra; Spanbauer, supra note 5. As Ramsfield points out, international students enter a new discourse community in U.S. law classes. See Ramsfield, supra note 11, at 158. They cannot succeed unless they learn these new legal genres and forms of communication and their professors understand that logic is culturally based. Id. Reviewing this literature, Cuciurean-Zapan concludes that the issue of plagiarism is itself enmeshed in issues of bureaucracy and regulation. Memorandum from Marta Cuciurean-Zapan to Mindie Lazarus-Black, supra. More research is needed on the relationship between rhetorical preferences, learning styles, writing styles, legal genres, cultural norms, and the education of international law students. See, e.g., Nilon, supra; Pennycook, supra; Spanbauer, supra note 5; Mark E. Wojcik \& Diane Penneys Edelman, Overcoming Challenges in the Global Classroom: Teaching Legal Research and Writing to International Law Students and Law Graduates, 3 J. LEGAL WRITING INST. 127 (1997). 


\section{impact on the students' ability to get through the program. ${ }^{64}$}

Admissions is also inevitably affected by the expectation that these programs be income-generating-what administrators and faculty at both schools referred to as "cash cows." This rendered them sensitive to the financial resources of the applicant:

You know, at some point, it's mercenary . . . . They say, "Well, my father is a lawyer." They tell you things in their essay that clue you that they are going to be able to fund themselves .... Maybe you admit them, but you don't offer a scholarship. But, if they come, that's a bonus to you; you've got a full paying student. ${ }^{65}$

These programs are, no doubt, significant sources of revenue. ${ }^{66}$ Based on interviews with administrators and faculty at these "regular" law schools, however, we argue that broader international changes, faculty interest in comparative and international law, enthusiasm (for many) for teaching international students, and shared recognition of the need for individuals with transnational expertise also explain the growth of the LL.M. programs in the United States. Indeed, based on the full set of interviews, we believe that to think of these programs simply as "cash cows" misses other important and complex phenomena driving the size of any particular program.

For example, we found that the number of students admitted to the programs for foreign attorneys grew substantially at one of the two sites we studied partly because they generated revenue, but also because faculty wanted to teach abroad and consequently created exchange programs and alliances with institutions overseas. In addition, a program administrator was very enterprising in setting up international connections. At the second site, in contrast, administrators made the decision not to expand their program. They were concerned about offering support services to foreign attorneys and recognized that if they grew too large, the quality of those services would decline to the detriment of the students. Hence, they deliberately limited the size of the admitted class of LL.M. students. ${ }^{67}$

64. Interview with Administrator \#6, supra note 44.

65. Id.

66. See Silver, A Report, supra note 4, at 155.

67. It has been interesting to find faculty members in the audiences of various conferences at which we have presented this work who have insisted that LL.M. programs for foreign students at their schools are simply "cash cows." Our empirical work at our two 
If much of the law school admissions process is predictable and guided by the rules of audit cultures, there are times when idiosyncratic and discretionary practices occur. We offer three examples of discretionary "checks" on the numbers game and evidence of informal axioms that work against the cliché that "anyone who can pay can come."

First, program officers as well as individual faculty members create networks and ties with foreign bar associations and other legal institutions that wax and wane over time, influencing who is admitted and from where. Admissions were influenced by these relationships with law schools and bar associations in other nations. While most students go through the standard application process, in some cases students were able to gain admission without a standardized test of English if they had successfully completed a partner program or held membership in a particular bar association. In both programs, the professional and sometimes fiscal support provided by members of foreign legal professional organizations can be critical in determining who eventually studies in the United States. Sometimes credentials are waived if a student has a good recommendation from a faculty member who has taught that student abroad. At each school, too, at least one member of the admissions staff held a law degree, had taught foreign attorneys overseas, and relied on what he or she had learned from those experiences when deciding students' preparedness to study at their home institution. Admissions staff members had become experienced about how well a student from school $\mathrm{X}$ will fare as opposed to a student from school Y.

Second, admissions officers are mindful of faculty who communicate resentment about having to work with foreign attorneys. These faculty members complain that international students slow down the pace of their lectures and necessitate expanded office hours because the students struggle with assignments. One administrator at the school on the East Coast explained: "I think there's certain ideas about

\footnotetext{
sites does not support this narrow view. Administrators at both schools spoke with pride about the ability of the faculty, administration, and staff to provide individualized attention to the LL.M. students. Such "hand-holding," as one administrator on the East Coast put it, takes resources. Interview with Administrator \#2, supra note 59. This was confirmed in interviews with Administrator \#3, supra note 62, and Administrator \#4, supra note 45 . The time and attention needed to guide the students both before and after they arrived in the U.S. was also confirmed in interview with Administrator \#9, School in Midwest. Without doubt, schools vary in their financial commitments to international LL.M. programs, with some schools "limiting their investment in international student programs so that each tuition dollar from an international graduate program student is likely to yield a higher proportion of net income compared with that generated by JD tuition." Silver, Coping with the Consequences, supra note 8, at 231.
} 
international students being more difficult to teach." She added that some professors could be quite cruel. For example, they will refuse to work with foreign attorneys who are "not up to par" with U.S. JD students in terms of their level of research and writing skills. ${ }^{68}$ Another officer at the school on the East Coast added two other faculty complaints. On the one hand, some faculty find that they cannot get through their lecture materials because foreign students ask too many questions. On the other hand, "[T] here's some faculty who say [international] students never talk and they're just very quiet."69 This last problem bears on pedagogical practice. How do you teach using Socratic Method if your students will not speak?

These concerns generate pressure to admit students who will not over burden professors and who will be "assets" in the classroom: "If in their essay or in their work experience, it's clear that they are engaged in something interesting, that's an interesting person ... well, maybe that person will be interesting in the classroom, and [then] the faculty will be happy . .."70 Thus, while administrators-some of whom are faculty themselves-are pushed to diversify and internationalize the student body at the law school, they are also accountable to other faculty who protest that internationalization lowers standards, slows down their lectures, and forces them to keep longer office hours. Thus, the faculty pressure administrators to go beyond the numbers when admitting international students. Understanding these examples allows us to identify when hegemonic reliance on numerical accounting practices will be challenged.

Finally, discretion plays a role in a paradoxical manifestation of what is euphemistically known in the admissions world as the "Wyoming effect"- the aspiration of schools to advertise "diversity." As Silver notes: "These programs internationalize the student bodies of law schools, which schools use as evidence of their international and even global characters." 71 These two schools communicated a specific desire for applicants from disadvantaged nations. Beyond providing evidence of geographic diversity, this enables schools to boast of their part in contributing to the alleviation of underdevelopment. One admissions officer who had regularly offered scholarships to lawyers from countries in Africa explained:

Basically, it's Africans who have no money at all, and if they can scrape together family and friends and

68. Interview with Administrator \#2, supra note 59.

69. Interview with Administrator \#3, supra note 62 .

70. Interview with Administrator \#6, supra note 44.

71. Silver, A Report, supra note 4 , at 154. 
scholarships to cover living expenses, if you can just let them come tuition free, they might just be able to get a degree. You know the whole issue of what role our academic institutions play in the capacity building in the developing world ... is a very complicated one but this is one piece of it. Can you give scholarships to people to come to help them to get a degree, to become part of the elite, the technologically trained elite in their society and make a difference .. . in the economic development of their country. ${ }^{72}$

Counterintuitively, the goal of international diversity in U.S. law programs serves to increase the "desirous" status of European students who are often among the most economically privileged. Admissions officers explained that students from European countries who now have greater access to education and jobs through their participation in the European Union have less reason to pursue studies in the United States, rendering them sought-after commodities. ${ }^{73}$ Latin Americans constituted another "minority" at both schools:

[I]f we get an application from someone from France or Italy or Germany, even a South American country . . . the admissions committee will take a vested interest in that person and maybe even offer them a scholarship because ... you don't want to become a school that is known for having one type of student . . . ${ }^{74}$

Two students-one from Lithuania and another from Ukraineenjoyed the double privilege that can result from this paradox. Both students were awarded a Fulbright, which covered most of their expenses, and both were awarded free tuition by the law school due to the desirability of students from their home nations.

Finally, in addition to these "disruptions" in the routine practices of the audit culture of LL.M. admissions, we want to draw attention to the remarkable amount of "self-selection" that characterizes the gatekeeping process. As Strathern argues, with the spread of audit cultures, "people check themselves."75 Self-selection into the LL.M. programs is remarkably effective and efficient-so much so that

72. Interview with Administrator \#6, supra note 44.

73. See SILVER, AGENTS OF GLOBALIZATION, supra note 8 , at 5 .

74. Interview with Administrator \#2, supra note 59.

75. AUdit CULTURES: ANTHRopological STUdies IN ACCOUNTABILITY, ETHICS, AND THE ACADEMY, supra note 16, at 4 . 
relatively few applicants are seriously "unqualified." Having reviewed six years of admissions files from each of these schools and a sample of files of students who were denied admission, we conclude that very few foreign attorneys applied to these programs without meeting the minimum qualifications. In the two years for which we examined rejected files at each of the schools, fewer than twenty applicants were rejected (and more than 100 students were admitted) in each school year. In one file, the admissions officer noted, "Looks like a son of privilege. Poor TOEFL, reasonable good grades overall esp. in $4^{\text {th }}$ year. Essay was not proofed by someone else. A good sign in my opinion. . . . I lean toward deny because of TOEFL." (Note that the applicant's essay was interpreted favorably due to its lack of "polish," making it "authentic.") Ultimately, however, the student was denied due to his score on the English exam, the most common reason why applicants were denied.

Other reasons for denial included failure to submit a completed file (unacceptable in audit cultures), "less than stellar grades," concern that the personal narrative had been "doctored," a general lack of professionalism in the application (as in the case of one applicant who submitted his essay on notebook paper and another who referenced the wrong school), and the occasional fraudulent letter of recommendation. For example, one file contained the following note: "Has refs from 3 law profs including one from U.S. Legal English Institution who clearly did not write the letter himself. If anything, he allowed the applicant to write the letter because it's not a native speaker's voice in lettergrammar and syntax clues galore ...."The applicant was denied when the admissions committee confirmed with the author of the reference letter that he had not written the recommendation. Of course, even a decision to admit a student does not guarantee the applicant's participation in the program. The admissions committee provides neither the first nor the last layer of audit; it is a component of a screening process that begins with the applicant's desire to apply and which does not conclude until the applicant has successfully navigated international, national, state, and institutional bureaucracies.

\section{ADMISSIONS NARRATIVES AS A GENRE}

While most of the admissions process in the LL.M. programs for foreign attorneys is grounded in the tactics and techniques of audit cultures, the personal narrative allows an applicant the opportunity to tell his or her own story, subject, of course, to the conventions of the instructions on the application and the self-imposed pressure on the student to write what he or she can to be accepted into the class. In the 
case of the admissions narratives, the schools' admissions forms and the requirement that each student provide a "personal statement" as part of the application process establish the scaffolding of the genre. One institution's directions for writing the narrative prompts applicants to describe themselves, their qualifications, their professional goals as relevant to the LL.M., any aspects of their application they wish to expand on, or any strengths and accomplishments not otherwise indicated on the application; students may "attach a separate sheet if necessary," and most do so.

In examining the applicants' narratives, our purpose is twofold. First, the narratives, and our discussions with the students about writing them, present a more complicated story about who journeys to the United States to learn U.S. law than what can be gleaned from quantitative analyses of admissions files or survey research. Because we have not conducted fieldwork in the most "elite" law schools, we are able to debunk some of the stereotypes that "all" foreign law students hail from the highest economic echelons of their countries of origin and that they are "only" interested in business and making money. The narratives give us insight into the lives and dreams of a remarkable group of people who are crossing linguistic, cultural, legal, and national borders for an array of purposes. Like the transnationally educated engineers and business entrepreneurs whom Saxenian referred to as "the new Argonauts,"76 the subjects of our study willingly travel a difficult path imagining a future in which they will not only do "well" financially, but also help their families across multiple generations, and their countrymen. Quite a few of our interviewees are concerned with people whose human and legal rights have been ignored or violated. Second, the narratives provide insight as to what foreign attorneys perceive about U.S. law, lawyers, and legal education. We begin with a discussion of the admissions essays as a genre as that concept has been defined and analyzed in linguistic anthropology.

As Bauman explains, a "genre appears as a set of conventional guidelines for dealing with recurrent communicative exigencies . . .."77 A genre is a formula for communication that is characterized by "a set of expectations concerning the ... unfolding of the discourse."78 Genres possess certain textual properties, such as boundedness, internal cohesion, and coherence. ${ }^{79}$ In addition, two features of genres proposed

76. See generally SAXENIAN, supra note 15.

77. Bauman, supra note 11 , at 85 .

78. Id. at 84 .

79. Id. 
by Bourdieu ${ }^{80}$ and developed by $\mathrm{Hanks}^{81}$ seem particularly relevant to the admissions essays. First, a genre adapts "to dominant power structures in the field to which it is addressed." 82 In other words, speakers must design their communication with content and style that is appropriate to the audience. This is "regularization." Hanks gives as some examples "a worker who pledges allegiance to the values of the boss, a politician who pushes buttons of his or her constituents by mentioning their concerns in a public address" and a "bilingual merchant who switches languages according to the preferences of customers . . . ."83 Second, speakers must also "signal the authentic, authoritative grounds on which they speak." This is "officialization":

To introduce oneself using a professional title, to wear the uniform of office, to speak of one's colleagues in the court or in the Senate, to refer to powerful people by first name as a display of familiarity, to describe an event using the technical language of law, medicine, military jargon, and so forth-all such moves involve building the authority of the speaker by association with dominant structures, and in this sense they enhance the quasiofficial status of the person's speech. Like regularization, officialization is a way of orienting the discourse practice to dominant structures in a field. The idea is that genres as kinds of practice imply different ways of achieving such orientation. ${ }^{84}$

Beyond engaging in both regularization and officialization, we identified in our sample of more than 300 narratives from the school in the Midwest five conventions that characterize the genre of the foreign lawyers' admissions essays to the LL.M. programs: (1) evidence of personal worthiness; (2) experience of the "West"; (3) a convention we call the "social structure of accomplishment"; (4) reference to what Mattei and Nader have identified as a "theory of lack"85; and (5) the portrayal of law as a resource for justice. By examining these

80. See Pierre Bourdieu, Outline of A Theory of Practice 21-22 (Jack Goody ed., Richard Nice trans., 1977).

81. See William F. Hanks, Language and Communicative Practices (1996).

82. Id. at 244 .

83. Id.

84. Id. at 244-245.

85. See generally MATTEI \& NADER, supra note 40, at 67-76 (explaining the "theory of lack" as the perception that Western countries and institutions hold towards cultures and peoples they see as less-developed or generally lacking something when compared with Western mores and ideology). 
conventions, we gain insights into their ideas about what would make them "desirable" to a U.S. law school's admissions committee, but also about their personal, social, educational, and work lives, and their impressions of U.S. pedagogy, law, and lawyers.

Not surprisingly, given the nature of an admissions essay, the first convention of the genre is the inclusion of markers of personal worthiness, including notions of identity and credentials. Students understand that they must "sell" themselves, developing in their statements what Bunten has termed the "commodified persona," (i.e., "a set of beliefs and practices in which an individual chooses to construct a marketable identity product while striving to avoid alienating him- or herself'). ${ }^{86}$ As she explains, forms of self-commodification may include "exploiting one's social background to create a commercial image, as 'gangsta' rappers do" and "putting one's best face forward, as in a job interview." 87

In the law school admissions narratives, students "sell" themselves by highlighting personal qualities, experiences, and accomplishments that qualify them for advanced legal education. For these students, law is not just a chosen field of study, but essential to who they are. Narratives frequently emphasize applicants' ambition, sense of justice, and analytical skills. Some students describe these qualities as tracing to their early childhood in ways that indicate their destiny as lawyers. One female applicant from China explains:

Since I was a little girl, I dreamed to be a lawyer, and then I would be able to protect those who are in trouble, to maintain the justice and peace of the society. I worked hard in the law school and had won ... scholarships ... I took an active part in public welfare activities. ${ }^{88}$

Some students point to specific incidents in their childhood that contributed to their development as budding lawyers. One male applicant from China writes:

86. Bunten, supra note 20 , at 381 .

87. Id.

88. As described in note 10, our sample of narratives from the school in the Midwest on which this discussion is based was gathered from the classes of 2003-2008 as fieldnotes. We went through the files for each class, recording verbatim comments having to do with students' backgrounds, education, work experiences, etc. As a condition of access to these files and to preserve the anonymity and confidentiality of the students, we agreed not to include any identifying marks other than that of gender and country of origin in our analysis of the essays. Accordingly, where we have drawn from these materials, no citation information is provided beyond the minimal demographic details included in the main body of our work. 
When I was twelve, the fight between my family and my neighbor brought about the injury of my brother. In the failure of the communal [sic] mediation, we resorted to law, and we got the fair judgment. The fruit we enjoyed drove me to make clear how we can settle a dispute fairly and I become [sic] increasingly interested in law.

Students' essays almost universally reference schooling and work or internship experiences to establish their worthiness for admission. They regularly establish the legitimacy of their credentials by describing the law school they attended as "the best in the country." One admitted Pakistani student describes passing his classes at a "top ranking institute in.Pakistan," and earning his LL.B. from "one of the best law schools in our jurisdiction." A male student from China describes his work for "one of the most famous and largest law firms in China."

Students further attempt to demonstrate their personal worthiness by sharing stories of acquiring cultural and linguistic capital that support their preparedness for study in the United States. In many cases, they portray themselves as "global citizens," outlining their previous studies in other nations and knowledge of foreign languages as evidence of their open-mindedness and global perspective. For example, one Austrian student emphasizes his "desire to travel and get in touch with foreign customs, languages, and people." Another student describes growing up in Africa and then moving to Europe: "Through this time, I experienced dramatically different cultures. It instilled in me a respect for tolerance, a search for broad-mindedness and a person [sic] interest in travel and in the pursuit of in-depth knowledge of various cultures."

A second convention common to the autobiographical essays is the students' identification with the United States or sometimes, as in the two examples just cited, "the West" more generally. Most often, the attorneys highlight their knowledge of the United States and English in a manner distinct from the other skills they list to "sell themselves." They frequently invoke books, films, specific U.S. laws, previous travel to the United States, and familiarity with U.S. cities. In contrast to the diverse and international student body revealed by the demographics, representing forty-one nations at the school in the Midwest, the narratives reveal a presentation of self that more uniformly emphasizes familiarity with and connection to Western culture.

To demonstrate their knowledge of U.S. law and history, for example, students draw on Oliver Wendell Holmes and Abraham Lincoln in their essays. Multiple students invoke one quote from Holmes: "The life of the law has not been logic; it has been experience." One applicant, citing Holmes, continues that if she is admitted into this 
program, "the study and experience there will be the wings of my dream." A male applicant from China writes that admittance to this program "would allow me to better follow the spiritual track of Abraham Lincoln, my idol since childhood, whose story led me into the palace of law." A number of students describe their enjoyment of television shows and movies that portray U.S. lawyers. A female Chinese student states in her essay:

When I was in high school, I saw a famous American movie titled "To Kill a Mockingbird." The movie impressed me deeply. I have a strong feeling of the importance of an excellent lawyer to the people, especially to the poor. From then on, I have long been dreaming to be a lawyer.

Other students reference landmarks or personalities identified with the city in which the law school is located as demonstration of their knowledge of the United States.

While students often present their language skills and cultural knowledge in a way that aligns them with the West, they also describe those skills as being in need of further enhancement that could be facilitated by study in the United States. They stress the significance of their personal development and their ability to compete in a global market. For example, a male student from Thailand outlines his prior studies of English and references a family member who has experience studying in the United States. He elaborates that his skills are deficient and communicates a belief that study in this program can help him:

English is very important in business and communication in the world .... I can't learn all languages in the world but can learn for the most famous and popular language which [used in] real life . . . English, to know more about law in many countries ... . Now I believe that I can communicate with foreigner so well but that isn't good enough to work in the position of attorney or judge. That's why I chose this program.

Similarly, a Chinese student describes her experience working on cases that involve foreign affairs, and explains her particular interest in the contrast between English and Chinese laws. This student also writes that she would like to attend this program to further improve her "English, orally and writing as well as listening. Moreover I want to widen my sight and become more knowledgeable about American legal 
systems and laws. I also would like to know more about American cultures, custom and history."

We call the third convention the "social structure of accomplishment." Students portray themselves as socially mobile with a desire to advance their economic, educational, and professional standing in a manner that coincides with the American expectation of movement "up the ladder" for those who work hard. In some cases students portray this movement as the result of individual accomplishment. For example, a woman from India who wrote that her "ambition now is to become a part of the United Nations," saw her program of study as "the first step to practice in the U.S.," and hoped "this step will take me to the next step up in my ladder."

In other cases, students portray their own mobility in an intergenerational context, either as an extension of, or in contrast to, the accomplishments of their family members. Much to the anthropologist's delight, kinship plays a remarkably prominent role in this regard. Students write frequently about the importance of law and lawyers in their families. They also write about their immediate kin instilling in them the value of education and the good works of relatives who have inspired them, sometimes in the face of incredible odds. One male student from India describes his family influence as follows:

I hail from a middle class Indian family, deeply religious and hard working, sincere and honest. Right from my childhood, my parents have inculcated in me a strong sense of responsibility towards my work, my family, and peers. My family has always encouraged me to strive towards success notwithstanding results.

A female student from China conveys a similar story, strongly emphasizing the role of her family in her success:

[M]y parents knew that the key to real success would lie in my education, and they toiled and moiled [sic] year in and year out to put that key into my hand, in a parental spirit and tradition that probably can only be found in China. Watching my parents working backs [sic] off every day, I acquired the kind of determination, drive, and sense of responsibility not usually expected of Chinese women in China. With my parents' unswerving support, I studied diligently and outperformed most of my classmates. For years, my academic report card was the main source of pride for my family. 
These invocations serve to support their upward trajectory and personal worthiness, framing law as their destiny.

The fourth convention surprised us, but lends strong support to Mattei and Nader's arguments about Euro-American legal imperialism and, more particularly, their discussion of "the theory of lack." 89 According to this theory, actors from both the First World and the Third agree that "the West" has much to offer "the rest." 90 In their essays and interviews, many foreign attorneys suggested that the United States is more "legally developed" than their home nations in certain areas of law. Interviewees specifically cited their interest in U.S. intellectual property, human rights, and immigration law. Some discussed quite candidly the "underdevelopment" of these forms of law in their countries of origin. This sentiment was not generally the case for prospective students from Europe, but it was common among foreign attorneys from Latin America, Africa, Asia, and the former Soviet Union. Students portrayed the United States as providing a prototype for new legal developments. For example, a female Japanese student wrote:

Since most of the real estate finance scheme in Japan was originally developed in the U.S., and since the U.S. has one of the most advanced taxation system which was often referred in recent Japan's tax reform [sic], it is most appropriate for me to study these topics in the U.S.

A Chinese student commented: "Since China's legal system is still being reshaped in reform, especially in intellectual property law after China's

89. See generally, MATTEI \& NADER, supra note 40, at 67-76 (explaining further the perceptions that Western nations hold regarding other economic, educational, and legal systems, which are generally viewed as lesser, i.e. "the theory of lack").

90. Collectively, the students' statements of deference are consistent with Mattei and Nader's "theory of lack." They argue that neoliberal theory and praxis have conveniently deployed the rule of law in "less developed" nations to serve U.S. politics and economics:

According to this vision, because modernization requires complex legal techniques and institutional arrangements, the receiving legal system, more simple and primitive, cannot cope with the new necessities. It lacks the culture of the rule of law, something that can only be imported from the West. ... Local shortcomings and 'lacks' are said to Id. at 20 have precluded progress in the development of the rule of law.

Today, we hear repeatedly that China lacks law or was and is averse to law .... . [and that] South American countries lacked sophisticated academic legal institutions. Latin American legal culture lacked skills of social engineering, something that could be found only in the US academy, thus justifying transfers of law.

Id. at 72 . 
entrance into the WTO, U.S. legal expertise can be helpful in considerable ways."

Other students refer to the United States with broader deference. For example, a Saudi Arabian student states in his personal narrative that he is "aware that this country has the top educational system in the entire world." A Polish male attorney writes: "Moreover I personally consider that USA, economically, culturally, and politically, is a leader as a Nation therefore would be really pleased to be able to commence study [in this program]." Still others reference the deficiency of their own legal system as a key element in shaping their lives and futures. A male Chinese student describes: "Born out of a poor peasant family, I had gone through the hardships of social inequality and injustice caused by the incompletion [sic] and imperfection of our legal system, which sowed the seed of love for equality and justice in the young heart."

A fifth convention strongly present within the admissions narratives is the emphasis on law as a tool for justice. For example, a female student from India states: "I feel that law is an instrument of social justice and it can be used to reduce human sufferings." This convention bridges the "theory of lack" with students' emphasis on the significance of Western law and culture, and their "commodified persona." Students discuss the conditions lacking in their home nations and the personal traits and experiences that drive their ambition to aid their country's development. They attribute their desire to attain a Western legal education to the fact that their own systems are unequipped to properly prepare them on this trek to attain a just legal system. As one female Chinese student explains:

China . . . struggles with judicial corruption and injustices. The existing judicial system, established under the conventional framework, is increasingly failing to facilitate the economy and establishment of a "healthy society." Injustices created serious obstacles on the development of China's legal system . . . . China needs a lot of legal professionals with formal training from western countries especially the United States to constitute [a] legal system with real justice and fairness and I wanted to be one of them.

Another student from China wrote: "I profoundly realized that law making was aimed to help the weak. I possess a desire to struggle if necessary through my life in establishing a society which will be free from expluitation and inequality." Other students emphasize justice as it relates to proper dispute resolution in the "just" handling of business 
matters. Earlier research with administrators suggested that international law students often prioritize business-related courses of study over other areas of law. In one such study, Silver:

[A]sked the graduate directors at the thirty-five surveyed schools about the students' course selections. Aside from particular required courses, graduate students at the thirty-five schools focused primarily on courses in U.S. law related to business issues, including corporations, securities regulation, and mergers and acquisitions. Other important areas of study mentioned by the graduate directors at these schools were international law, intellectual property, and negotiations or alternative dispute resolution, but the graduate directors stressed that these areas of study were clearly secondary to the business-related courses. 91

Our data, however, suggest that some students are motivated to take these business law courses not only because these fields will increase their employability in the world of high finance, but also because of their belief that U.S. business law can help shape a fair and more ethical business climate in their home countries. A male student from Thailand provides a good example of this convention: "Without proper laws, education and their implementation, there are no incentives for pirates to cease their activities .... Currently Intellectual Property and I.T. [international treaty] law is in a stage of infancy in Thailand." He describes his goal "to further broaden and strengthen my knowledge and experience ... by attending an eminent program in the United States," and states that he "would like to return to Thailand ... better equipped to make a positive difference." A male student from Panama wanted to develop his skills as an advocate: "We must show sacrifice and devotion in good advocacy. ... It is a good feeling when one as a professional solves a problem by using the appropriate legal tools that the justice system gives us." To cite one last example of this convention, a male attorney who had entered law school as China's economy was undergoing radical transformation explained in his essay:

At that time, China was in a transition from a planned economy to a market economy, but introduction of the market mechanism did not bring the expected efficiency, prosperity, and justice. Industrialization forced peasants

91. Silver, A Report, supra note 4, at 168. 
to abandon their land but did not offer them a place in the city .... The harsh reality urged me to explore the legal system for market players, especially the issues of corporate law in a transitional society.

This attorney's work experience enhanced his concern for the challenges wrought by China's entry into the market economy. After graduating law school, he served as a judge and witnessed the need for a more effective legal system from the bench: "I felt the need to return to school and find a solution for these real issues." He intended to "help build up the rule of law in China when I return." 92

The conventions that students utilize in their admissions essays intersect in complex ways. Note the paradox between the first three conventions and the fourth. In their essays, students juxtapose a discourse of accomplishment with a discourse of "lack." They establish their personal worthiness, skills, identification with the West, and place in a broader social structure of accomplishment, while acknowledging the "developed" nature of U.S. laws-laws that often serve as models for governing new forms of national and international concerns in business, commerce, treaty relations, and human rights. The students frame the "goals" that the application instructions suggest be addressed at the same time that they portray U.S. law as the model for the present and future internationalization of law and the legal profession. Learning U.S. law and legal English will allow them to improve themselves, their businesses, their governments, and the world more generally. Westernized legal education becomes the pathway for these students to address concerns regarding justice in their countries of origin.

92. An astute administrator in the Midwest law school described the "Chinese profile" of LL.M. students enrolled in that program as including three types of students:

A very small group that say they want to be teachers, that they want to come back and that they want to share what they've learned... They are people who have been studying something, now they want to study something at a comparative level, then they want to come back and share what they've learned, to help China improve, for example, its legal doctrine, and improve its practices in this area ... Another group wants to make money and they want to be successful business people, and they're just very clear about that. ... And then the third group is the social justice group, and they tend to have had some horrendous experience. They didn't know they were privileged, they grew up, they went to college, all of sudden, they volunteered at a clinic, and they discovered how horrible things were, which they never knew because their parents protected them. ... And now they want to participate in making China even better than it can be. You know, leading China forward, helping poor and downtrodden, and making sure that miscarriages of justice, which are so common, that they are champions for those people. So that's the Chinese profile.

Interview with Administrator \#6, supra note 44. 
In Part III, we have explored LL.M. admissions narratives as a genre characterized by regularization, officialization, and five additional conventions, drawing examples from student essays from China, Saudi Arabia, Austria, Pakistan, Poland, and elsewhere. In Part IV, we offer a more complex presentation of these interwoven conventions through an analysis of one student's personal essay. We have changed the student's name and omitted information that might reveal his identity. "Asmar" is from India. We close the discussion with a comparative analysis of admissions narratives from the school on the East Coast.

\section{ASMAR'S ESSAY AND OTHER NARRATIVES}

Asmar begins his essay with a statement about social mobility: "I find myself at a point in life where a year of foreign legal education would enable me to graduate to another level of professional achievement and personal fulfillment." He next references his accomplishments to establish himself as a candidate worthy of selection into the program. He describes his educational credentials, which includes an LL.B. obtained from a government law college in India, and his work as an attorney. In the following statement, he intertwines conventions one (personal worthiness) and three (the social structure of accomplishment): "My time in Mumbai as a law student and professional has given me a foundation on which I can and must build. For this, it is imperative that I study abroad. I am not only driven by ambition, but also by the quest for knowledge for knowledge's sake." This statement is consistent with Ballakrishnen's finding that among her sample of Indian lawyers, the decision to pursue an LL.M. degree was often "a personal choice for validation and achievementindependent of the possible labor market gains it could offer."93

Convention four, recourse to the "theory of lack," appears several times in Asmar's narrative. Asmar acknowledges that a new international legal order is being established by specifically mentioning the World Trade Organization's dispute settlement system. In his essay, he describes India as:

93. Ballakrishnen, supra note 23 , at 2465. Ballakrishnen explains: 'India's regulatory resistance to opening its legal market, along with the broadening stratification of its domestic profession, has created institutional and organizational cultures in which American legal credentialing is not afforded any uniform favor." Id. at 2447-48. Why, then, would Indian attorneys seek that credential? A surprising number of Ballakrishnen's interviewees pursued the degree for reasons having to do with their own personal satisfaction and sense of accomplishment. See id. at 2465-66. As we suggest here, the narratives and interviews analyzed for this study also support the point that personal and intellectual goals draw international lawyers to U.S. law schools. 
One of the significant economy [sic] and [a] strong participant in world trade. Equally India is at another level, still a country that is striving for [a] basic level of human dignity and livelihood. It is this paradox that makes India such a relevant country from the perspective of international trade and development work that is being undertaken by various institutions.

Asmar appreciates the "emerging international legal system" and connects that new international legal system to his wider goals:

It is the interplay between [the] domestic and international system[s] that will increasingly govern the work of a lawyer, and I hope with my existing knowledge of Indian domestic law and my soon to be acquired insight into international law, I will be preparing myself better for a career in this dynamic profession.

Asmar's aspirations, however, are not limited to improving his own career. He also references convention five (justice) as motivation for seeking admission, writing about his "desire to bring about social changes" in India once he has his degree. His specific interests include international trade, international business, international arbitration, intellectual property, and social justice framed in part as "patents rights versus human rights." He voices the need for Third World countries to make patented medical treatment available. He highlights the importance of lawyers in addressing such social challenges:

I have not lost sight of the public role that I have to play. I come from a small community in a large city. Mumbai is a city of contrasts and vast disparities. . . The grating poverty, surprisingly, coexists as a peaceful neighbor to the mansions of money and power. I am not suggesting that there is a total apathy to this abject situation, but there is surely much more that can be done in redressing the social and economic problems of the day.

Consistent with convention two (association with Western culture and goals) he documents his hopes for "personal success . . . which brings with it monetary success." In his conclusion, he uses a quote that further marks his identification with the United States citing "the lines of Robert Frost who wrote: "There are miles to go before I sleep, miles to go before I sleep.' This summarizes the philosophy that drives me." 
Asmar's essay demonstrates how students incorporate into their essays several of the conventions we have identified. However, we still needed to learn if the use of these conventions, in various combinations, was characteristic of applicants at the school on the East Coast. To answer this question, we analyzed the personal statements of the enrolled students there for the year 2008-2009.

To explore whether the "commodified persona" that emerged among the Midwest applicants was present at our second site, we examined sixty-two narratives in the sample from the East Coast school. The patterns held-each of the five conventions appears in the personal statements of these applicants. As would be expected in an admissions essay, "personal worthiness" characterized all of the student narratives. The convention we call the "social structure of accomplishment" was always a very important theme, as was kinship. Students often wrote about the impact of their fathers and other family members who were lawyers. Also very prevalent was the convention of describing law as a tool for social justice. The key difference was that the sample was marked by fewer discussions of identification with the United States or the "West" more generally and fewer invocations of the theory of lack. We can only tentatively explain why this may be the case. Relative to the Midwest school, there was indication that the East Coast program admitted more students who already had experience working and studying in the United States. ${ }^{94}$ If this is the case, students may have felt it less necessary to stress an affinity for U.S. or Western values in their essay.

In short, the admissions narratives constitute a genre characterized by regularization, officialization, and five additional conventions: students' personal worthiness, markers of identification with the United

94. The quantitative data gathered by Globokar as part of this study revealed a greater prevalence of applicants who already held visas, a green card, or citizenship at the East Coast school. Despite substantial missing data, there was indication on file that at least eighty-six students held some form of U.S. residency at the time of application (thirty-one individuals claiming non-resident alien status, seven permanent residents or asylees, twenty with claims of citizenship, another twenty-seven that proclaimed citizenship along with providing a green card number, and one who provided a green card number); and at least fifteen reported already holding some form of non-student visa-six B1/B2 (business/tourist) visas, five B2 (tourist) visas, two $\mathrm{H}-4$ visas (for families of $\mathrm{H} 1 \mathrm{~B}$ visa holders), one H1B (temporary specialty worker) visa, and one Al (diplomatic) visa. Collectively, this reflected at least $20.9 \%$ of the East Coast sample held some form of residency, citizenship, or non-academic visa. By contrast, despite less missing data, our research found that the Midwest school had only fifteen students reporting citizenship, another nine reporting some form of residency status, and another twenty with some kind of existing non-student visa (L2, R-B2, two L1s, K1, six H-4s, three F-2s. two B1/B2s, an $\mathrm{A} 2$, and three $\mathrm{E} 2$ (investor) visas), accounting for $11.5 \%$ of the student body in the years under study. 
States and the developed "West," a social structure of accomplishment, a theory of lack, and a focus on law as a tool of justice. As in the case of Asmar's essay, many personal statements in the applications to each school included markers of multiple conventions. The interplay of these conventions reveals the complex nuances of students' commodified personas, transcending the cursory profile that could be gleaned from demographic or nation-of-origin statistics alone. The narratives reveal students' paradoxical self-representations as worthy but deferent, justice-seeking but personally ambitious, and invested in their home countries but sharing an intellectual kinship with the United States. How did the narratives compare to what we learned from the students themselves?

\section{What They Wrote, What They Say, AND Who They ARE}

After we collected the narratives, Lazarus-Black interviewed students in the LL.M. programs at each school. ${ }^{95}$ As noted earlier, she conducted interviews with fifty students from twenty-two countries. She asked students what brought them to the United States to study law, their experiences in writing the applications, and how they acquired and managed resources to fund their education. As will become clear later in our discussion, we found consistency between our own and earlier studies in the reasons foreign lawyers give for coming to the United States to study. Our interviews shed additional light on the ways that students' motivations vary by age, previous education, work experience, and, sometimes, the vicissitudes of legal practice in their home countries. Surprisingly, the students were almost universally panicked by the experience of writing their admissions essay. The lawyers were accustomed to taking tests to get into educational institutions but unaccustomed to writing about their personal experiences, education, work lives, or future goals. How did they cope? And, once admitted, how did they pay for their studies? The interviews give depth to the quantitative data and the personal statement narratives and lend further support to our contention that LL.M. programs are increasingly attracting a very heterogeneous group of international students. We selected excerpts from interviews with students from Pacific-Asia, Europe, the former Soviet Union, and Latin America to illustrate what we see as the new diversity of the LL.M. class.

95. To protect the identities of our interviewees, we made no attempt to match any one particular subject with the narrative he or she had written months or, sometimes, years before. 
We begin with the students' reasons for attending an LL.M. program. These foreign attorneys were highly motivated and all of them had multiple reasons for wanting to study in the United States. Their goals can be clustered in four general categories, although in any one individual case the attorneys' purposes mostly crossed these groupings.

First, they had plans that involved professional and career advancement in their country of origin, the United States, or across international borders. Professional and career advancement included such things as promotion in a firm or office to which the lawyer intended to return, pursuing a different legal specialization, expanding current business and legal opportunities, or changing from a career as a lawyer to becoming a judge or a professor. Some foreign attorneys had entered the program in part as a prerequisite for taking the New York bar; others wanted to bypass the low bar passage rate that is characteristic of some countries, like Japan. ${ }^{96}$ For others, the LL.M. was a credential that would allow them to work at least temporarily in the United States through the Optional Practical Training Program (OPT). ${ }^{97}$

Second, some students included in their responses "personal reasons," as in the case of students who had married U.S. citizens and one interviewee with dual citizenship who decided she wanted to move permanently to the United States. ${ }^{98}$ These attorneys chose law years ago, and they were committed to practicing their chosen profession in another country.

A third frequently cited motivation was intellectual, as we saw in "Asmar's" personal narrative. ${ }^{99}$ Given that our interviewees were intellectually gifted and had been "selected" over the course of their lives into some of the finest schools and universities in their countries of origin, and also "self-selected" into the program in which they had enrolled, it is no surprise to find them continuing to pursue intellectual interests.

A fourth set of responses included the desire to learn about law that was not available or which attorneys described as "underdeveloped" in their home country, a goal sometimes connected to pursuing social

96. See Mayumi Saegusa, Why the Japanese Law School System Was Established: Cooptation as a Defensive Tactic in the Face of Global Pressures, 34 L. \& SoC. INQUIRY 365, 371 (2009) (showing the historically low bar exam pass rate in Japan at 2-5\%).

97. Our data revealed that most of the students in our sample held F-1 visas, which allowed them to apply to study one or two semesters at the law school and to apply to remain in the United States for additional training in their field.

98. Interview with Student \#25, School on East Coast.

99. See Ballakrishnen, supra note 23, at 2467. As noted earlier, access to an intellectual environment was a common motivation in Ballakrishnen's study of Indian returnees. 
justice. As part of the process of achieving these goals, all of the students for whom English was a second language wanted to gain proficiency in English, especially legal English. Both at school and afterward, they hoped to build friendships as well as work-related networks with attorneys from the United States and other countries. In short, the interviews, like the narratives, revealed a diverse and dynamic portrait of who these students are.

An established lawyer who was a partner in a law firm in China, 100 for example, wanted to improve his English, to learn the common law system, and to understand how U.S. lawyers practiced in firms. His long-term goals included offering new services to his current clients in China, attracting new clients from the international community, and establishing networks with attorneys he met in the United States with an eye toward developing future relationships. Perhaps reflecting his seniority and experience, he was one of the few interviewees in this study to have successfully found an internship under the OPT program. ${ }^{101}$ Another senior lawyer from China worked in a government post for eight years before she enrolled in the program at the school on the East Coast. She wanted a chance to study U.S. law, to live abroad, and she hoped this experience might open new doors when she returned to China. ${ }^{102}$

Younger attorneys talked about their future careers. A twenty-fouryear-old woman from Thailand explained that she would undertake to complete not one but two LL.M. degrees, ${ }^{103}$ thereby establishing qualifications that would make it possible for her to pursue a career as a judge in Thailand:

[For] the judge system in Thailand ... [there are] like three kinds of exams. The first one is if you only have a bachelor's, then you can take the judge bar exam with other requirements ... . But in this exam, there'll be a lot of people and the percentage will be very low. The second one would be finish the LL.M. in Thailand, which in Thailand usually takes two years. They get more percentage who pass. And the third one would be to have

100. Interview with Student \#32, School in Midwest.

101. Students were interviewed at different stages in the LL.M. program, so we are not able to determine how many of those who expressed an interest in participating in the program actually succeeded in finding a position.

102. Interview with Student \#14, School on East Coast.

103. Interview with Student \#39, School in Midwest. 
two LL.M. for the two years, so if I came back, I would have more possibilities. 104

A young French attorney had enrolled in the LL.M. program at the East Coast school:

Because I wanted to improve my English and I was very interested in the American system when I was studying in France, so I just-and I think also it can bring me a lot of opportunities because the LL.M. is recognized in France by many companies, and as I am specialized more in international law, so that's good for me. ${ }^{105}$

She hoped to find employment under the OPT program and to sit for the New York bar before returning to France. ${ }^{106}$ A Chinese woman expressed similar motivations. ${ }^{107}$ She wanted to improve her English, find temporary employment in the United States to gain experience beyond the classroom, and take the New York bar exam before returning to China. ${ }^{108}$

A student who was in the LL.M. program for personal, professional, and intellectual reasons was a woman in her late thirties who had an established career in China as a notary. ${ }^{109}$ She was in the United States because her husband, an engineer, had been hired by a U.S. company. She explained that she had always wanted to study abroad, but she had never been able to do so. Now that she was married and living here, she could earn another degree. She imagined she would eventually take the New York bar, but she first needed to improve both her knowledge of U.S. law and her English skills.

Marriage had also brought a Colombian attorney to the United States. ${ }^{110} \mathrm{He}$ had met his future wife while visiting his family who lived in the United States. His wife worked for her father in the city where the law school was located. Formerly, he practiced law and occasionally

104. Id.

105. Interview with Student \#24, School on East Coast.

106. Id.

107. Interview with Student \#38, School in Midwest.

108. Lazarus-Black found these sentiments were very common among students from the Asia-Pacific region, many of whom were interviewees who had just completed their undergraduate degrees in law.

109. Interview with Student \#33, School in Midwest. Note that the qualifications to work as a notary, as well as the duties and tasks that they may perform, vary from country to country and from state to state in the United States. In civil law countries, notaries are usually attorneys.

110. Interview with Student \#5, School on East Coast. 
taught in a law school in Colombia. He had applied to the program he was attending on the recommendation of the attorney who had helped him get his green card. He felt his future depended upon passing the bar. Over the years, he had practiced what anthropologists call "occupational multiplicity," 111 engaging in a variety of different jobs to help his family meet their monthly bills.

Intellectual and professional goals motivated a twenty-five-year-old student from Lithuania. ${ }^{112} \mathrm{He}$ was already at work on a master's degree in his home country, had some experience teaching law students, and hoped to become a professor. His passion was international law and he believed that he could not teach that subject well until he understood both the civil and the common law traditions. He was one of the few interviewees who specifically stated he wanted to learn to "think like an American lawyer." A recent graduate of the East Coast program also decided that he wanted to become a professor, and therefore pursued a doctorate in law. ${ }^{113}$

Women's rights inspired a young lawyer from China.114 She was unusual because while she was enrolled in the LL.M. program she participated as a volunteer at an NGO that worked on behalf of people "with problems," including abused women and children, for which she received course credit. When she completed her LL.M. program, she considered applying for a master's degree and asked Lazarus-Black to read her personal essay. Her essay emphasized how much she had learned about women's rights by studying in the United States and that she hoped to use that knowledge to work on behalf of women in China. About six months after the interview, the student wrote to LazarusBlack to inform her that although she had not been accepted into the program in the United States, she enrolled in a doctoral program in Beijing and was specializing in women's rights. This case combines the desire to learn about an area of law deemed underdeveloped "at home" with a strong commitment to advancing human rights.

The desire to work for social justice, combined with practical and professional matters, inspired a woman who was originally from Colombia and who had married a U.S. citizen a few years before her interview. ${ }^{115}$ She chose the East Coast program because it offered

111. See Lambros Comitas, Occupational Multiplicity in Rural Jamaica, in SYMPOSIUM on Community Studies in ANTHRopology: ProceEdings of THE 1963 ANNuAL SpRING MeEting of THE AMERICAN ETHNOLOGiCAl Societry 41-50 (Viola E. Garfield \& Ernstine Friedl eds., 1964).

112. Interview with Student \#2, School on East Coast.

113. Interview with Student \#6, School on East Coast. In this case we are not identifying the student's country of origin to protect the interviewee's anonymity.

114. Interview with Student \#34, School in Midwest.

115. Interview with Student \#18, School on East Coast. 
courses in all of the subjects she was interested in, was local, and was affordable. After graduating from a law school in Colombia, she worked first in a small firm that specialized in family law and later at a bank that handled mortgages. At the time of the interview, she had decided that she was most interested in family and immigration law, explaining that "she was a person who liked to help people." 116 She intended to take the New York bar and then to pursue a career in which she could assist immigrants in the United States. She was not sure if that meant working for a firm or for the government.

Foreign attorneys' motivations for attending U.S. LL.M. programs show consistency over time.117 For example, this study confirmed Silver's research among students who graduated ten or more years ago, which uncovered several functions that U.S. graduate programs serve in the careers of transnational lawyers:

[The LL.M. programs] provide an important link in the professional networks of transnational lawyers; they offer graduates credibility (including important experiences in legal and business English) that enables them to connect with elite national and international law firms and raise their status in their home country legal professions; and they equip graduates with a legal terminology crucial for participation in the international legal services market. ${ }^{118}$

In a more recent publication, Silver lists nine motives that respondents in her survey of 1996, 1998, and 2000 LL.M. graduates cite as having led them to pursue U.S. graduate legal studies. The motives include: "[e]xpansion of professional opportunities in home country;" "[i]nterest in a particular area of law;" "[d]esire to improve English skills;" "career advancement;" "[d]esire to live in the USA;" "[i]nfluence

116. Id.

117. See Silver, Agents of Globalization, supra note 8, at 9-17; Silver, A Report, supra note 4, at 156-158; Silver, Coping with the Consequences, supra note 8, at 233-238; Silver, Variable Value, supra note 3, at 41-42. Based on his interviews with law students in China, Erie found: "Obtaining an LL.M. abroad, preferably from the U.S., is an unspoken rule for advancement in most international law firms." Erie, supra note 18, at 75 n.49. Dordević found studying in an LL.M. program provided a different perspective on law in Serbia, new directions in teaching law, and the opportunity to pursue moot court competitions. See Dordević, supra note 18, at 73. Studying alumni of U.S. LL.M. programs using two case studies, graduates in China and Germany, Silver finds that from the perspective of the law firms the value of the degree for employment mobility is decidedly different in each place. See Silver, Variable Value, supra note 3, at 6.

118. Silver, A Report, supra note 4, at 144. 
of colleagues/friends who had earned an LL.M.;" "[p]ath to a job in the USA;" "[f] amily considerations;" and "[n]ecessity for US bar exam."119

The admissions narratives and interviews analyzed for this project suggest that these foreign attorneys remain motivated to pursue a graduate degree in law based on multiple intersecting goals. Our findings differ from Silver's on two points. First, it was rare for an interviewee to volunteer that the "influence of colleagues/friends who had earned an LL.M." served as a motive for their studies. Second, our narratives and interviews uncovered interests in advancing human rights, improving peoples' social welfare, ensuring fair business practices, and serving as a resource in their country of origin to advance law in new directions. Moreover, our different methods allowed us to track additional information about how the age of the attorney, the stage of his or her career, or the requirements of practicing law in the attorney's country of origin influenced the decision to pursue a graduate law degree in the United States. Nevertheless, the consistency of the attorneys' motivations is interesting given the vastly different configuration of the practice of law and the market for lawyers in the United States that Tamanaha marks as characterizing legal education and the profession in recent years.

Even if the data shows consistency over time in the reasons why foreign attorneys decide to study abroad, there is no data in the scholarly literature, to our knowledge, about the next step: what is it like to apply to a U.S. law school? For most students interviewed in this study, the admissions essay represented a genre that was unlike any other they had faced before. Throughout Europe, Latin America, and Pacific-Asia, students test into programs; exam results are the key to where they may or may not study in the future. In response to the question of whether she had experience writing a personal essay, one student from China explained: "No. We do not need to introduce ourselves to the university. We just take exam and the grades will introduce you." 120 The male attorney from Colombia in the program on the East coast answered tersely: "Never."121 This was the case for almost every interviewee at each school. ${ }^{122}$

119. See Silver, Coping with the Consequences, supra note 8, at 234 tbl.2. In this paper, Silver examines foreign attorneys' motivations for enrolling in LL.M. programs to better understand how U.S. law schools can both attract more of these students and improve those students' experiences once they are admitted.

120. Interview with Student \#36, School in Midwest.

121. Interview with Student \#5, supra note 110 .

122. The few exceptions included: three students who had to write personal statements to secure internships in law firms in Germany, Korea, and Ireland; a young woman who received a master's degree in the Midwest before deciding she wanted to continue her education in law; a woman from Poland who had written a personal statement as part of 
For most students, the personal statement was a challenge that entailed considerable homework. Like U.S. students applying to college, graduate school, or law school, students used books and the Internet to try to figure out what U.S. schools "wanted," showed their statements to friends or family members, alumni of the law schools to which they were applying, and occasionally to a teacher or a member of their firm to ensure that their essay, and in this case their use of English, was acceptable. An interviewee from Turkey ${ }^{123}$ told Lazarus-Black: "I made a search online and I found that book, it was like, 'How to Get into U.S. Colleges' or something like this. It actually tells you how to apply but it doesn't tell you how to apply specifically for law schools."

The attorney from Colombia first asked his wife and then did more research on his own: "My wife told me more or less what they wanted to know is this, in their application, but I look online and also, and read, I like to read these forums for people, foreigner students, read what people say." The woman from Colombia also consulted her husband (a U.S. citizen) when she wrote her essay, but in addition she spent time on Google. The young woman who returned to China to attend a doctoral program had no previous experience with this genre. She obtained models for her narrative from two friends who had earlier applied to the school. She also showed her statement to her father's friend because he taught English.

The woman from Thailand who was considering a career as a judge was unusual in the effort she exerted in working on her essay. She took courses about U.S. law at home before applying to the LL.M. program. When she decided she wanted to study in the United States, she contacted several alumni of the program, including a friend who gave her a copy of her own essay as a model. She also showed her essay to her brother, who was a lawyer. In accord with the importance of kinship disclosed in the narratives, both her brother and her father encouraged her to study law. She explained that her father favored law as a career for her because he believed that if she became a lawyer or a judge he would have the peace of mind that would come as a result of knowing she could live independently. Finally, she sent her essay to one of her former teachers from the United States and received suggestions via email.

In contrast, a young woman from Russia explained that she asked three or four friends to read her essay:

her application for her first law degree in Poland; and the senior woman from China mentioned earlier who had written a statement to secure her government job. Interview with Student \#14, supra note 102.

123. Interview with Student \#21, School on East Coast. 
just to give some opinion if it's within the standard U.S. style . . . . So basically I didn't change a lot, but I wanted for my personal statement to reflect my personality rather than be standard, so even some of the mistakes they would correct . . I would still keep it the same . . . ${ }^{124}$

She explained "I wanted my statement to reflect my personality" and if the school was not interested, it would not be the right place for her. ${ }^{125}$ The student from Lithuania asked no one for help. He joked that it would have taken him too long to explain to anyone what kind of essay he had to write! ${ }^{126}$

In short, the foreign attorneys in this sample found the experience of writing an admissions essay, and of applying to a U.S. law school more generally, stressful. ${ }^{127}$ Not surprisingly, they asked for advice from friends and family members, alumni of the schools to which they intended to apply, faculty, members of their bar associations with connections to those schools, and information they located online. ${ }^{128} \mathrm{We}$ did not collect data on the precise number of schools each student applied to, but we do know that in choosing a school they were influenced by alumni; their experiences in taking classes that the

124. Interview with Student \#9, School on East Coast.

125. Id.

126. This student had spent considerable time online before writing his essay. Asked what people had written about in the essays he had read, he said students talked about family background and work experience. We have no way to measure the influence on the LL.M. applicants of the "how to" sources they consulted on the Internet. Given their lack of experience in writing a personal essay, it is not surprising that nearly every student mentioned reading sample essays online. Interview with Student \#2, supra note 112.

127. One young male student from Thailand interviewed at the school on the East Coast appeared to be an exception when he first claimed that writing the essay was not challenging because he got assistance from alumni and friends. He subsequently contradicted himself: "If you tell the truth they are not going to accept me. . . . It was challenging because for me I am a blunt person. In a personal statement you present something good, not something blunt." Therefore, he and his friends collected versions, studied "the structure - you know the introduction, middle, and conclusion . . all this is a system that I did not learn in Thailand." Interview with Student \#23, School on East Coast.

128. There has been a lot of recent controversy about the use of agents who recruit international students to colleges in the United States, and particularly about middleclass Chinese parents who seemingly will stop at nothing to ensure that their seventeenyear-old children are accepted into a U.S. university. See Eric Hoover et al., Admissions Group Adopts New Policy on Paid Recruiters, CHRON. HIGHER EdUC., Oct. 4, 2013, at A16; Jon Marcus, Fraud Fears Rocket as Chinese Seek a Place at Any Price, TIMES HIGHER EDUC. (June 13, 2013), http:/www.timeshighereducation.co.uk/news/fraud-fears-rocketas-chinese-seek-a-place-at-any-price/2004701.article. None of the foreign attorneys Lazarus-Black interviewed for this study reported that they had used an agent to assist them in applying to the LL.M. program in which they had enrolled. 
schools had offered in their home countries; friends or relatives living in or near the cities in which the law schools were located; the "reputation" of the school, by which they meant the reputation of the faculty; specializations in subjects of interest to the students; and, importantly, the school's reputation for welcoming international students.129 In addition, of course, the students all paid close attention to the costs of tuition and the expenses of living overseas.

Given that international students must prove that they have sufficient funds for living in the United States for the period during which they will be enrolled in school, as well as the findings in the extant literature about how foreign law students finance their LL.M. degrees, we were not surprised that many of our own interviewees included students who were financially independent or from well-to-do families. The partner in the Chinese law firm, ${ }^{130}$ discussed earlier, is an obvious example. He financed his education through his personal resources, but the interview revealed that he also sometimes advised clients in China through email and telephone. One presumes that meant he was earning at least some income. The senior woman who worked for the government in China relied on personal savings, family support, employee compensation, and a scholarship from the Chinese government. ${ }^{131}$ The Thai student who was considering becoming a judge depended entirely upon her family. ${ }^{132}$ She described her father as a "manufacturer." Her mother worked with him in the business.

A second student from Thailand was also supported by his family. ${ }^{133}$ His parents worked together in their family-run business that produced storage products. The Chinese student who returned to China to pursue her doctorate in the field of women's rights was funded by her parents and a partial scholarship from the law school. ${ }^{134}$ It is important to point out, as so many students did in their interviews, that the reasonable cost of the two programs in which we conducted our research was critical to why they had chosen these schools.

The narratives had already given us insight, however, into the heterogeneous family backgrounds and work experiences of the foreign attorneys. By talking to the students we learned just how much some of

129. Some attorneys at both schools mentioned to Lazarus-Black that they planned to take the New York bar exam, but those attending the school on the East Coast cited this more commonly. That school's proximity to New York, but less expensive cost of living, was among the reasons for choosing the school. A few students had previously visited the city in which the school was located.

130. Interview with Student \#32, supra note 100.

131. Interview with Student \#33, supra note 109.

132. Interview with Student \#39, supra note 103.

133. Interview with Student \#40, School in Midwest.

134. Interview with Student \#34, supra note 114. 
them and their families struggled to amass financial support so that the student could study abroad. An exceptionally gifted young woman from China, for example, was pursuing an LL.M. degree in China on full scholarship; the Midwest school offered her a one-semester scholarship to study as an exchange student. Her mother worked for a transportation company and her father was a "driver." 135 She had helped put herself through her undergraduate law degree by working part-time. Studying in the United States was possible only because the law school paid all of her tuition. 136

An exchange student at the East Coast school had help from her parents, but also a modest grant from the Irish government "for being from a low-income family." ${ }^{37} \mathrm{Her}$ parents worked in the arts at a time when Ireland was in a recession, there was "mass unemployment," and law was "one of the worst hit professions." 138 She described her family's economic circumstances this way: "I would say lower-middle class .... We live comfortably, I went to good schools, and we have a nice house and so on, but we did not, we wouldn't have high earnings at all. My parents aren't actually together, so I'd say, economically, we'd be lowermiddle class." 139

The father of the student from France worked in the armed services and her mother was a housewife. This student had no family support to fund her education. She had a scholarship from an international organization and a bank loan. When asked why she decided to attend this particular school, she revealed that her decision was partially made for her by her bank:

I was looking for schools in the United States that offered the program for foreign lawyers and [this school] was among the most affordable, so I considered the money because I have to take a loan in France and as you know, I don't know if you know, but the tuitions [sic], there is no such high tuitions in France, so the bank system is not really adjusted to that. So one day I remember, because at first my dream was to go to [Ivy League School on the East Coast] the tuition and fees are very high, and I went to my bank and I asked for a

135. Interview with Student \#36, supra note 120.

136. Id.

137. Interview with Student \#1, School on East Coast.

138. Id.

139. Id. 
loan, and it had to be 40,000 Euros, and they just were shocked. They are not use [sic] to that. ${ }^{140}$

Several interviewees described fluctuations in their families' socioeconomic status. For example, the male attorney from Colombia recounted his family's struggles in pursuit of higher education and economic success. ${ }^{141}$ His grandmother had never learned to read or write, but she was very determined that her children go to school. $\mathrm{He}$ described his mother and her brother as "very poor" and therefore only able to attend public school. His parents, however, sent their children to private Catholic schools. He used language to index the change in the family circumstances between his grandparents' and his parents' generations: "We were middle class, but I would say that, I grew up as a middle class peoples [sic] but my parents and my grandparents, I would say they were low, in the bottom .... If you would talk to her, you can see the difference, totally." 142 In particular, he attributed his own success to his mother:

[S] he always said even if we are not rich we have to send our children to the best school, and I went to the best high school and I was studying with people who was, had good positions in my city, in a prestigious place, and this helped me a lot in the future. ${ }^{143}$

$\mathrm{He}$ and his brother were very "lucky" to get into the private school because "it's hard, they reject many people, it's a lot of people, and they usually accept people who had relatives that were there before. I don't know, we were lucky that we got that position."144

The woman from Colombia who had married a U.S. citizen worked with her husband in his business for several years before she could afford to attend the LL.M. program. She was paying her tuition from their personal savings and a bank loan. She continued to help her husband at work on a part-time basis as she pursued her studies.

The student from Lithuania had witnessed his family's class position rise and fall. During the recession of the late 1990s, his father had to sell his own small business and go to work for another company. His mother also lost her job and eventually went overseas where she found work caring for the elderly. Over the years, his family had been

140. Interview with Student \#24, supra note 105.

141. Interview with Student \#5, supra note 110.

142. Id.

143. Id.

144. Id. 
"most of the time middle class," but as he explained, the meaning of "middle class" in his country was quite different.145 For example, because the country was formerly under Soviet rule, almost everyone "at home" had a home. It was clear to him that that was not the case in the United States. How was he funding his legal education? A Fulbright grant provided for all of his living expenses and the school granted him a full-tuition scholarship.

An interview with the East Coast program student who decided to become a professor revealed a similar story. ${ }^{146}$ During most of his childhood, his father was away and unable to send support to the family. He described his mother as a "business woman" who "had owned small shops and lost small shops. At the time [at one time] we had seven shops and then we were bankrupt, like a couple of times." At the time of the interview, he was on scholarship, tutoring, and pooling resources with his wife to complete his degree.

In short, the heterogeneity of the foreign attorneys in terms of countries of origin, age, family, and work experience, as well as their very different social and economic backgrounds, create a diversity in the classroom that is more complicated than we previously imagined. The students all had good transcripts, but they were differently prepared for their U.S. legal education, particularly in regard to their English oral and written skills. As the quantitative data revealed, they were generally older than typical JD students, but to focus on the fact that their average age was thirty or thirty-one is to miss the vastly different set of skills the exchange student held in comparison to the partner in the law firm. Similarly, while the narratives first alerted us to the complex social, political, and economic backgrounds from which the students came, the interviews confirmed the students' experiences with inter- and intra-generational upward and downward mobility, as well as the lengths to which some families went to ensure that the student was able to study in the United States. Scholarships from international organizations and a law school's willingness to cover tuition are therefore critical to allowing students from non-elite backgrounds to pursue their legal education in the United States.

\section{DISCUSSION}

If Tamanaha is correct, the students sitting in the seats of tomorrow's law schools will be quite different than the students we have been accustomed to seeing in the past. It is clear that a great many

145. Interview with Student \#2, supra note 112.

146. Interview with Student \#6, supra note 113. 
more of them will be international students. We sought to better understand the implications of this transition by talking to those who are most integral to the process-the administrators who admit and otherwise attend to foreign attorneys enrolled in international LL.M. programs, and the students who compose this population. Our quantitative analysis of a sample of LL.M. students from two programs, one on the East Coast and one in the Midwest, revealed a student body that was neither predominantly white nor male nor uniformly privileged. The largely Asian, majority female population at these two schools align with Healey's observation that broader international forces shape international student bodies. Nations with educational systems that have been unable to keep up with demand during times of rapid economic or legal development feed an international market that is filled by programs such as those we studied. ${ }^{147}$ The students were undoubtedly privileged by many measures, but it was also true that some overcame significant economic barriers to attend these programs and that, for some, their pursuit of an LL.M. was a step taken in part to counterbalance class- or gender-based disadvantages they faced in their home countries.

Through direct examination of the "material culture" of admissions, including students' applications and personal essays, interviews, and fieldwork, we gained insight into the onerous, multilayered, multinational processes of structural and institutional selection. As these students come together in time, space, and purpose, their paths act and are acted upon by a diverse array of international, federal, state, local, and law school regulations. As the admissions officers made clear to us, one does not just decide to come to the United States to study law. A student must meet criteria in his or her country of origin as well as in the United States, and that process is one of constant negotiation in which a sudden change in nation-to-nation relations can have a profound effect on who can study where. Moreover, we learned that even before they contemplate studying law in the United States, the students have themselves undergone a very extensive process of selection in their country of origin. Already quite aware of "who they are," they self-select when they apply to law schools in the United States.

Within the law schools, specific and timely economic, social, and political circumstances influence the applicants' access to legal education. Informal networks that develop between U.S. administrators and faculty, as well as between administrators and their counterparts at other institutions and bar associations overseas, also influence applicants. We documented in this study a process of gatekeeping that

147. See Healey, supra note 41 , at 349 . 
is heavily informed by audit culture: a culture obsessed with concerns for "accountability," "objectivity," "authenticity," and "economic sustainability." Administrators read applications, including the students' personal statements, for evidence of training in English, the quality of the schools from which students graduated, past grades, work experiences, and indications of who can afford to attend their school. In line with audit cultures more generally, these administrators are under. pressure to admit applicants who conform to specific quantitative thresholds and use techniques of commensuration to justify their decisions.

Still, embedded within apparently objectified and homogenized auditing processes, we detect that admissions decisions are also affected by the more nuanced and subjective matters such as concerns with the applicants' "survivorship," and with the administrators' need to navigate relationships and politics, both intra-office (including discussions in faculty offices) and internationally (including written and informal agreements with partners in institutions in other nations). This study of admissions illuminated sometimes idiosyncratic and discretionary moments in the gatekeeping process and some of the paradoxes of internationalization and border crossings more generally. There are published standards for admission, but administrators "read" rules, regulations, and applications to decide who has the "appropriate" social, political, economic, and linguistic capital to warrant admission into their programs.

"Standards" and "minimum scores" are "bent" when a faculty member writes in support of a particular student she has taught abroad, when there are networks to a particular bar association that must be preserved, or when a student applies from a country that is not wellrepresented at the school. "Bending" admission rules may favor students from under-represented Second, Third, and Fourth World countries, but students from the more competitive First World market, for example the European Union, can also benefit from flexible admissions standards. Our study challenges stereotypical notions of privilege by revealing circumstances in which administrators seek students from countries of disadvantage, but come to value students from "the West" for their contribution to "diversity." 148 The multilayered

148. A recent study of personal statements in which students applying to the University of Michigan responded to the question of how they imagined themselves to be contributing to the "diversity" of the institution demonstrates that, at least for this group, students are interpreting diversity to include variables such as religion and internationalism. The earlier assumption that "diversity" means "racial diversity" is under contestation. See Anna Kirkland \& Ben B. Hansen, "How Do I Bring Diversity?" Race and Class in the College Admissions Essay, 45 LAW \& SOC'Y REV. 103, 127-32 (2011). See generally Bonnie 
processes of examination are sometimes contradictory. Applicants may share stories of hardship and survival to speak to their character and appeal to the admissions officers' desire for some students of disadvantage, but, at the same time, they must be able to reach certain financial thresholds to secure the visa necessary for attendance.

The analysis of admissions narratives as a genre provided a more in-depth understanding of who these students are. We found operative in the narratives evidence of the convention of "regularization." Foreign attorneys learn to conform to the style and implicit and explicit values they uncover in sample admission essays that they find on the Internet or through fellow students, alumni, teachers, or family members. Like Hanks' example of "the worker who pledges allegiance to the values of the boss" and the "bilingual merchant who switches languages according to the preferences of customers," 149 the foreign attorneys pledge their faith in U.S. law and legal education, and they spell out in English their past accomplishments and future goals. As most applicants are already lawyers, they can "signal the authentic, authoritative grounds on which they speak," the convention Bourdieu identified as "officialization."150 Their personal statements revealed five additional conventions: personal worthiness, "Western" experiences, a "social structure of accomplishment," a "theory of lack,"151 and law as a tool for justice. The attorneys created a "commodified persona."152

The students' essays reveal the struggle of balancing English proficiency with authenticity, personal capacity with the need for further education, and deference to the United States and to cultures of "the West" more generally, even as they claim the legitimacy of the qualifications earned in their countries of origin. Students' presentations of "self" involve their drawing on experiences of advantage and disadvantage to demonstrate their "worthiness" for admission. The narratives complicate the stereotype that foreign lawyers in LL.M. programs are predominantly elites who "rule the

Urciuoli, Excellence, Leadership, Skills, Diversity: Marketing Liberal Arts Education, 23 LANGUAGE \& COMM. 385 (2003) (deseribing the use of the concept of diversity in college promotional discourse that has come to replace the term "multiculturalism" because it is understood to include a broader array of differences). As Urciuoli writes, "[m]ulticultural nearly always refers to something connected to racial markedness; diversity often does not." Id. at 389.

149. HANKS, supra note 81, at 244.

150. Id. at 244 .

151. See generally MATTEI \& NADER, supra note 40, at 67-76 (exploring Western perceptions of law, and Western views of other cultures in the legal framework).

152. Bunten, supra note 20 , at 381 . 
world."153 Our findings also counter earlier claims that foreign attorneys in LL.M. programs in the United States are only concerned with business. To the contrary, a fifth convention-law as a tool of justiceindicated a desire to use the degree to teach and to work with subordinated social groups.

Asmar's personal statement was just one example of how these conventions overlapped and intertwined within individual student narratives. Additionally, it demonstrated an example of a student's desire for "professional achievement and personal fulfillment" which, in this case, he imagined as work that would make patented medical treatment available in countries that lacked such treatment. Both the narratives and the interviews conducted with students at each of the two schools underscored the foreign attorneys' intentions to work toward broader social goals. ${ }^{154}$

Indeed, the student interviews complemented and confirmed both their motivations for pursuing an advanced law degree from a U.S. program and the projected future goals that attorneys wrote about in their personal statements. Personal, intellectual, professional, and other practical motivations drove the students. The attorneys wanted to learn English, benefit from education in forms of law that differ or are more developed in the United States than in their home nation, and earn the credentials necessary to advance their careers, some for personal reasons but, for others, in the pursuit of broader justice-based goals. In most cases, students were driven by several of these motivations simultaneously. The interviews also evidenced the diversity among these students' experiences. The students included young men and women who had just finished their post-secondary education as well as senior partners and government officials. Some were worldly travelers;

153. See Michael D. Goldhaber, They Rule the World: One Year LLM Programs at U.S. Law Schools Are on the Rise Again, Attracting Fledgling Power Brokers from Around the World, AM. LAW., Sept. 1, 2005. The article focuses on a number of powerful political, judicial, and corporate world leaders who have LL.M. degrees from elite programs, such as those at Columbia, University of Pennsylvania, Harvard, and Cambridge. According to Goldhaber: "Whether they aim for the public or private sector, LL.M.s are often subsidized by private foundations, governments, and law schools." Id. He cites as evidence the Ford Foundation's sponsorship of more than 250 Chinese graduates between 1982 and 1997 and the Fulbright Program for the U.S. State Department, which increased legal scholarships by $400 \%$ from 29 in 1995 to 122 in 2004. Id. Without denying the role of LL.M. programs in educating world leaders, we want to suggest that today's students include lawyers who will work in a wide array of transnational legal arenas.

154. For example, some students were intent on using their degree to make contributions in areas such as immigration (Interview with Student \#18, supra note 115) and women's rights (Interview with Student \#34, supra note 114). As we have demonstrated, the concern for social justice was often evident in the personal statements included in the admissions files. 
others were leaving their country for the first time. They were disparate in their command of oral and written English. Some arrived with several compatriots, while others found themselves as the single representative of their nation. Originating from around the globe, these students ranged from the economically and socially privileged, to the upwardly mobile, to attorneys trained abroad but who were now living as part of the U.S. working class.

The requirement of an admissions essay, while typical of the U.S. college admissions process, was both literally and figuratively "foreign" to the experiences of applicants from other nations. Many of their home countries rely solely on grades, exam scores, and other objective measures for admissions, so the endeavor of writing a personal statement was largely a new experience, prompting students to seek out tips and feedback from others. The foreign attorneys made use of resources on the web, family and friends, teachers, and persons they believed had good grammatical skills. We read the narratives for purposes other than to determine the "fit" between an applicant and a particular school; we were interested in the essays as a vehicle to understand how foreign attorneys present themselves to gain access to a U.S. law school and to discern who will participate in the next generation of globally trained lawyers. Along the way, we also captured a glimpse of their impressions of U.S. law, U.S. lawyers, and U.S. citizens more generally. In the narratives, "we" are a people who include Atticus Finch in To Kill a Mockingbird, Abraham Lincoln, and Oliver Wendell Holmes. "We" offer a place to learn legal English, the lingua franca of transnational law, the common law system, and some of the latest innovations in fields like international law, intellectual property, and commercial and trade law. The genre of a law school application, of course, presents "us" in a favorable light, but we agree with Kirkland and Hansen that admissions narratives represent more than "mere posturing." 155 As they argue, the fact that the essay is "posed and presented in certain stylized ways does not disrupt its power as a political message (both sent to the applicant by posing the question and sent back by the essayist)." 156 Like college students who are reconceptualizing the meaning of "diversity," the subjects of Kirkland and Hansen's study, foreign lawyers "weigh in" on changing perceptions of what legal education should be, what lawyers need to know, and how the practice of law is changing. Moreover, if there is a certain lopsided quality to some of these narratives, the analysis of the interview data that recounts the students' experiences once they are in law school and

155. Kirkland \& Hansen, supra note 148, at 104.

156. Id. at 104 . 
living in and around its borders adjusts that favorable view of "us"- but that is another story. ${ }^{157}$

We close with two observations derived from the empirical research we have described here that warrant further attention and investigation of administrators and faculty who admit, advise, and teach foreign law students; scholars who are interested in the changing nature of legal education and the legal profession; and, more generally, scholars seeking to understand the complex processes that inform the globalization of law. First, our research suggests we are witnessing a process of inclusion in both legal education and the legal profession more generally of persons who were previously denied access to its ranks. That process is in some ways analogous to but also remarkably different from that described for an earlier time period.

During Franklin D. Roosevelt's administration (1933-1945), "inclusion" into law school and the legal profession came to mean the inclusion of members first of the lower classes and non-Protestants, and later of women and persons of color. ${ }^{158}$ Very roughly speaking, by the 1980 s one could enter law school and the profession without being outright "barred" because of religion, ethnicity, race, or gender. ${ }^{159}$ The

157. See generally Mindie Lazarus-Black, The Education of Feng, Dan, Matt, and Natalia: Foreign LL.M. Students as Liminal Subjects (Nov. 16, 2011) (unpublished manuscript) (on file with author) (exploring views from lawyers trained in the civil law tradition studying in the United States).

158. The literature on the history of legal education and the changing composition of the legal profession in the United States is vast. See, e.g., JEROLD S. AUERBACH, UNEQUAL Justice: LaWYers AND Social Change IN MODERN AMERICA (1976); JoHn P. HeINZ \& Edward O. Laumann, Chicago lawyers: The Social Structure of the Bar (1994); JoHn P. HEINZ, ROBERT L. NELSON, REBECCA L. SANDEFuR \& EDWARD O. LAUMAN, URBaN Lawyers: The New Social Structure of the Bar (2005); DunCan Kennedy, Legal Education and the Reproduction OF Hierarchy: A Polemic against the System (2004); ROBERT B. STEVENS, LAW SCHOOL: LEGAL EDUCATION IN AMERICA FROM THE 1850S TO THE 1980S (1983). Garth compares and contrasts the current controversy surrounding access to legal education with the rhetoric of crisis that ensued around the time of the Great Depression. Bryant G. Garth, Crises, Crisis Rhetoric, and Competition in Legal Education: A Sociological Perspective on the (Latest) Crisis of the Legal Profession and Legal Education, 24 STAN. L. \& POL'Y REV. 503 (2013). Garth argues:

The Depression-era proposals were, at best, thinly veiled attacks on the law schools that provided access to minorities and immigrants.... Today, the argument is couched in favor of access to law school for the relatively disadvantaged, but the result looks quite similar-an effective denial of access in the name of saving lower classes from 'bad decisions.'

Id. at 516 .

159. A few studies demonstrating the diversification of legal education by the $1980 \mathrm{~s}$ include RICHARD L. ABEL, AMERICAN LAWYERS 85-111 (1989); AUERBACH, supra note 158, at 293-299; Karen Berger Morello, The INVISIBle Bar: THE WOMAN LAWYER IN America, 1638 to the Present 248 (1986); Barbara A. CURran, Women in the LAW: A 
much more recent internationalization of legal education, however, is changing the meaning of the terms of "inclusion." The new relevant variables affecting gatekeeping include the wider politics of interstate relations; the vicissitudes of international, federal, state, and local law; the operation of audit cultures both internationally and in the law schools; the ability to muster a bank account sufficient to please U.S. bureaucrats; and a certain proficiency in English as the lingua franca of international law. Thus, based on our study of student admissions files and interviews with administrators and foreign attorneys at "regular" law schools, it appears that structures of privilege play by different rules at the international level, with the significance of race, class, gender, religion, and ethnicity overshadowed by variables such as language, country of origin vis-à-vis current political relations, and ability to muster economic and other symbolic resources (even under great hardship). As we have demonstrated, some of our interviewees spoke passionately about their own and their families' downward and upward mobility. The findings also suggest the benefit of engaging in research that spans a cross section of law schools; students' biographies, experiences, and trajectories are likely to vary based on the local, regional, and institutional contexts of the schools they attend, including the relative elitism of schools. Nonetheless, the diversity revealed in our sample should not be interpreted as tantamount to a dismantling of the very real race, class, and gender barriers that continue to characterize the profession. ${ }^{160}$ Indeed, Tamanaha's prediction of the future homogenization of law schools casts a somber shadow for those who wish to see legal education and membership in the occupation of law as ever more, rather than less, inclusive.

Second, our findings demonstrate that law schools are important sites for scholars to examine the content, structures, and processes of globalization. Our research supports Aman's argument that understanding legal dimensions of globalization requires us to engage simultaneously a global perspective on domestic affairs and a domestic perspective on globalization. ${ }^{161}$ Prospective LL.M. students from other

LOOK AT The Numbers (1995); Kermit Hall, The Magic MirRor: LaW in AMERICAN HISTORY 288-291 (1989); David Wilkins, A Systemic Response to Systemic Disadvantage, 57 STAN. L. REv. 1915, 1923, 1927-1942 (2005); Audrey Wolfson Latourette, Sex Discrimination in the Legal Profession: Historical and Contemporary Perspectives, 39 VAL. U. L. REV. 859, 893-909 (2005); Statistics on Minority Enrollment, LAW SCH. ADMISSION CoUNCIL, http://www.lsac.org/jd/diversity-in-law-school/racial-ethnic-minority-applicants/ minorities-in-legal-education-statistics (last visited Oct. 28, 2014).

160. See generally Ronit DinOvitzer et AL., AFTER THE JD: FIRST RESUlts of A NATIONAL STUDY OF LEGAL CAREERS (2004) (reporting on the composition of the legal profession for new attorneys); DINOVITZER, supra note 6.

161. See Aman, supra note 6, at 1. 
nations face laws and regulations in both their countries of origin and the United States that challenge their ability to dwell legally in the United States. And, as in the case of immigrants, these laws and regulations articulate sources of privilege and power accessible to some persons but not others. In the context of law school, we find support for Aman's contention that "globalization is embedded in our institutions . . . by virtue of legal arrangements . . . that draw global 'forces' into everyday life, and vice versa." $162 \mathrm{We}$, too, find that globalization "yields pervasive social effects-some of them broadly homogenizing, some of them diversifying in highly specific ways." 163 As we have described, the two LL.M. programs for foreign attorneys we studied, and the administrators and students we talked to, shared many commonalities, but there were also differences. Administrators at the two schools used their discretionary powers differently, entered into different types of agreements that waxed and waned with schools and bar associations in other countries, and made different decisions about how large to grow their programs. Similarly, while the students who applied to these schools were drawn to U.S. LL.M. programs for many of the same reasons, serendipitous factors, such as the experiences of family and friends who had previously attended the school, the school's reputation among their schoolmates or members of their bar association, the strategic marketing of a program by a faculty member or an administrator, the need to live in a certain city, or the cost of tuition, led a student to a particular program. Thus, scholars interested in law's role in globalization need to respond to the transnationalization of legal education in ways that take into account the operation of sometimes contradictory forces and events. The journey of international lawyers to study in the United States is the amalgamation of global and local processes, and the students' biographies speak to varying forms of privilege and hardship in this venture. As sites of globalization, law schools are creating new legal experts who will reinvent the future meaning of being a lawyer and doing a lawyer's work.

\section{ACKNOWLEDGMENTS}

We want to express our appreciation to the deans of the Midwest and East Coast law schools for allowing us to conduct this research. We were in the offices of an assistant dean in charge of international

162. See id. Aman investigates the globalization of law through the development of multilateral treaties addressing climate change; the voluntary regulation of conditions of employment by corporations; and the implementation of welfare, prison, and immigration laws, which now sometimes include outsourcing and privatization.

163. Id. 
programs in the Midwestern school $a$ lot as we gathered admissions narratives, and we could not have completed this work without the generous assistance of several administrators in that office. Thank you for making our work possible and answering our questions. We hope you will find our analysis interesting and useful as you plan for the future. We were also welcomed in several administrative offices at the school on the East Coast. We acknowledge with gratitude members of administration, faculty, and students at both schools who agreed to be interviewed. Thank you for your time and for sharing your experiences. You have broadened our worldview and deepened our understanding of what it means to cross many different borders.

We thank Marta Cuciurean-Zapan, Nikky Greer, Marie Schelle Solano, and Brendan Tuttle for their invaluable assistance in gathering bibliography, transcribing tapes, and research on selected topics for this project. We gave abbreviated early drafts of sections of this manuscript at the Law and Society Conferences in Denver, May 28-31, 2009, and in Chicago, May 26-30, 2010. We are grateful for responses from members of those sessions and the audiences who raised good questions we hope we have now answered. Carole Silver read these and other conference papers, offered astute advice, and welcomed our participation in studying this new legal landscape. Lazarus-Black also thanks Bill Black, Wendy Espeland, Paul Garrett, Glenn Gottfried, Gordon Gray, and William Garriott for their insightful comments on work-in-progress. 